\title{
A Review of Phenotypic and Genotypic Methods for Detection of Drug Resistance in Mycobacterium tuberculosis
}

\author{
Shadi Parsa ${ }^{1}$, Saman Soleimanpour ${ }^{2}$ (D), Mohammad Derakhshan², Leila Babaei Nik ${ }^{3}$, Raha Mir ${ }^{3}$, Nafiseh Izadi $^{1}$
}

1. Microbiology and Virology Department, Faculty Medicine, Mashhad University of Medical Sciences, Mashhad, Iran

2. Antimicrobial Resistance Research Center, Bu-Ali Research Institute, Mashhad University of Medical Sciences, Mashhad, Iran

3. Tuberculosis Reference Laboratory- Northeast Iran, Mashhad University of Medical Sciences, Mashhad, Iran

ABSTRACT

Tuberculosis is one of the most dangerous infectious diseases in the world and causes nearly two million deaths each year, especially in developing countries. Meanwhile, multidrug resistance tuberculosis (MDR-TB) is due to the resistance of Mycobacterium tuberculosis (Mtb) strains to two effective first-line drugs, isoniazid and rifampin, which is increasing worldwide. MDR-TB strains are mainly caused by inadequate treatment of TB patients. The emergence and spread of these strains is an obstacle to the control and management of tuberculosis as well as a threat to the World Health Organization's goal of eliminating the disease by 2050. Proper management of MDR-TB relies on early recognition of the disease. Recently, phenotypic and genotypic diagnostic methods have been developed to rapidly identify MDR strains in tuberculosis patients. Some of them are also economically suitable to use in developing countries. Proper treatment of patients with drug-resistant TB requires the rapid detection of resistant strains and appropriate drug administration. Regular monitoring of patients' side effects of medications as well as enhancing the quality of bacterial tests is essential to identify resistant strains. Therefore, in this review, we will describe the available phenotypic and genotypic tests for drug-resistant tuberculosis detection and discuss their advantages and limitations.

Keywords: Mycobacterium tuberculosis, Drug resistance, MDR-TB, Drug susceptibility test

Received: 2019/12/26; Accepted: 2020/03/05; Published Online: 2020/04/09

\begin{tabular}{|c|c|}
\hline Corresponding Information: & $\begin{array}{l}\text { Saman Soleimanpour, Antimicrobial Resistance Research Center, Bu-Ali Research Institute, Mashhad University of Medical } \\
\text { Sciences, Mashhad, Iran. Email: soleimanpours@mums.ac.ir }\end{array}$ \\
\hline (c) (1) (5) & $\begin{array}{l}\text { This is an original open-access article distributed under the terms of the Creative Commons Attribution-noncommercial } 4.0 \text { International License which } \\
\text { edistribution of the material just in noncommercial usages with proper citation. }\end{array}$ \\
\hline
\end{tabular}

Use your device to scan and read the article online

\section{Introduction}

Tuberculosis has been one of the deadliest infectious diseases in the world and remains a public health threat (1). In 2018, the World Health Organization reported more than 10 million (between 9 and 11.1 million) new cases of tuberculosis (2). The emergence of multidrug-resistant Mycobacterium strains is increasing due to various factors such as AIDS epidemic, irregular use of anti-TB drugs, increased use of injectable drugs and migration from endemic areas (3). Multidrug Resistance Tuberculosis (MDR-TB) is defined as resistance to two effective first-line drugs for the treatment of tuberculosis, isoniazid and rifampin (4). MDR-TB strains with extensive drug resistance (XDR-TB) are described as resistance to all oral fluoroquinolones and at least one second-line injectable aminoglycoside (amikacin, caproomycin and kanamycin) (5).

In 2018, the World Health Organization estimates that \%3.4 of new cases and \%18 of previously treated MDR-TB cases, as well as \%8.5 of MDR-TB cases associated with XDR-TB (2). In order to prevent the spread and spread of MDR-TB and XDR-TB strains and 
the emergence of new strains, simple, rapid and accurate diagnostic methods are needed to identify drug resistance among patients with tuberculosis. Unlike many bacteria where antibiotic resistance occurs due to motile genetic elements such as plasmids, transposons and integrons, mycobacteria have a chromosomal drug resistance and are often caused by mutations associated with a limited region of the genome. This resistance can be transmitted to subsequent generations of bacteria and disrupt TB control and treatment programs $(6,7)$. In the following, the mechanisms of action and resistance of isoniazid and rifampin drugs as well as the advantages and limitations of TB drug sensitivity diagnostic tools and methods are presented to evaluate and evaluate the advantages and disadvantages of each of these methods.

\section{Conventional phenotypic methods on solid medium}

The most commonly used egg-based culture media is the Levenstein-Johnson (L) medium.

\section{Proportional method}

In this method, growth rate of Mtb on the control medium without antibiotic is compared to the growth on the drug-containing medium to determine susceptibility or resistance. The number of colonies counted in the control tube indicates the number of live bacilli in the total number of microbes cultured and the number of colonies in the antibioticcontaining tube indicates the number of resistant bacilli in the same number of microbes. The ratio of the first number to the second number is called the critical ratio or percentage of resistance, indicating that the strain is resistant or sensitive. For different drugs the criterion of resistance (critical ratio) varies. For example, the percent resistance for both isoniazid and rifampin is $1 \%(26,27)$.

\section{Absolute Concentration Method}

In the absolute concentration method, a standard amount of bacteria is inoculated in a solid medium such as $\amalg$ containing different concentrations of the antibiotic. The lowest drug concentration that inhibits bacterial growth (less than 20 colonies in 4 hours) is defined as resistance criteria. (28).

\section{Resistance Ratio Method}

This method is similar to the absolute concentration method and is the ratio of the drug MIC for the tested strain to the MIC for the standard H37RV strain performed under the same conditions (29).

\section{Conventional Phenotypic Methods in Liquid Medium}

Using liquid media instead of solid media reduces the cultivation time from 8-12 weeks to 3-7 weeks. These environments can also be stored for longer periods at room temperature (30).

\section{BACTEC 460 TB SYSTEM Radiometric Method}

The culture medium used in the radiometric method is 7H12 (12A) medium. Mtb metabolize palmitic acid containing radioactive carbon in this medium and release $\mathrm{CO}_{2}$-labeled gas in the upper part of the culture medium (31). This gas is collected and measured by a semi-automatic device called the BACTEC 460 TB SYSTEM. Determining the amount of radioactive carbon in $\mathrm{CO}_{2}$, the growth rate of $\mathrm{Mtb}$ is accurately determined. This growth rate is called the GI index, which indicates a positive mycobacterial culture if it is 10 or more (32).

\section{Mycobacterial Growth Indicator Tube (MGIT) Method}

This method uses modified Middlebrook 7H9 with a fluorescent extinguishing oxygen sensor mounted at the end of the tube. In addition to the compounds in the 7H9 environment, it contains a mixture of antimicrobial agents such as PANTA (polymyxin, amphotericin, nalidixic acid, trimethoprim and azlocillin) to prevent the growth of gram-positive and gram-negative bacteria. The consumption of oxygen in the fluorescence medium and the detection of this light in the presence of UV lamps is a reason for the growth of Mtb in the tube (34).

\section{Versa TREK Method}

This method uses modified Middlebrook 7H9 with a mixture of antimicrobial agents such as PVNA (polymyxin, vancomycin, nalidixic acid, and azlocillin). This method is capable of simultaneously identifying mycobacterial growth and drug sensitivity to first-line drugs by measuring changes in oxygen consumption (35-36).

\section{Modern Phenotypic Methods}

These methods include mycobacteriophage expressing luciferase, colorimetric methods, and nitrate reduction test.

Genotypic Methods for the detection of MDR-TB resistant strains

Molecular methods are capable of detecting genes that are effective in generating drug resistance and resistance-related mutations in $\mathrm{Mtb}$ target genes. Using these methods, the results are obtained within 1 to 2 days and can be directly applied to smear positive sputum isolates and other clinical specimens.

\section{Amplification Refractory Mutation System (ARMS)}

ARMS-PCR is a simple and rapid method for identifying point mutations, restriction fragment length polymorphisms (RFLPs) or small deletions during DNA fragment sequencing (46). This method is 
also called allele-specific PCR or PCR amplification of specific alleles (PASA).

\section{DNA-Sequencing Method}

DNA sequencing is the most widely used genotypic method for detecting drug resistance, especially firstline TB drugs in Mtb. Sequencing is the most accurate and reliable method for mutation detection and is used as the gold standard method (49).

PCR-Single Stranded Conformation Polymorphism Analysis (SSCP)

PCR-SSCP is a simple and rapid method that can be used to determine the presence or absence of a mutation in a specific region of DNA based on the pattern of DNA migration in the gel. As a rapid screening tool, it has high accuracy in the detection of drug resistance, especially in MDR-TB cases (51).

\section{PCR-restriction Fragment Length Polymorphism}

The PCR-RFLP method is a simple, rapid, and inexpensive method used to detect changes in one or more codons found in drug resistant and mutation sequences (53).

Determination of Antibiotic Susceptibility by Real Time PCR

The Real Time PCR method is very similar to the conventional PCR method. Similar to PCR, a sequence is amplified using specific primers. But Real Time PCR differs from conventional PCR in quantitative amplification of sequences. In Real Time PCR, the amplification of the product is detected by using the fluorescent marker in the reaction. These fluorescent markers are designed to produce light by binding to DNA if they replicate. The Real Time PCR method is divided into two categories: (1) the use of nonspecific fluorescent markers using DNA-bound dyes such as SYBR ${ }^{\circledR}$ Green or Eva green (2) the use of dedicated fluorescent markers using probes Target genes.

\section{High Resolution Melt-HRM Real Time PCR}

This method first amplifies the resistance-related genes by Real Time PCR and then the PCR product is heated in the presence of specific DNA fluorescent dyes such as SYBR-Green and Eva-Green. Colours are specific for double stranded DNA. At the beginning of the rise in temperature, the signal is high because at low temperatures most DNAs are double stranded. As the temperature continues to rise, DNA begins to separate and single-strand and thus loses colour. (62) In the HRM method, differences between different genotypes are determined by differences in the melting curve. That is, even a single change in gene sequence (mutation) can affect $\mathrm{Tm}$ and cause the fragment's melting curve to change.
Determination of Antibiotic Susceptibility by Line Probe Assay (LiPA)

Line probe assay (DNA probe assay) is a method based on DNA Strip Test, which involves DNA extraction, amplification of a gene associated with resistance, and subsequent hybridization of PCR products labelled with oligonucleotide probes fixed on the strip. These oligonucleotides are highly sensitive and do not bind to complementary DNA if they contain even one different nucleotide.

\section{INNO-LiPA Rif. TB (Innogenetics)}

This method searches for rifampin resistance mutations in the $r p o B$ gene. Since rifampicin resistance is an indicator for the detection of MDR-TB, positive results of this method detect about $90 \%$ of MDR-TB samples (68).

\section{Xpret MTB/RIF (cephied) Method}

The Xpret MTB/RIF method is able to simultaneously detect Mtb complex and its resistance to rifampin antibiotics directly from sputum collected within two hours. It should be noted that a high proportion of rifampin-resistant strains are associated with concomitant resistance to isoniazid (approximately 95\%) and individual resistance to rifampin accounts for only about $5 \%$ of the resistant strains. Therefore, rifampicin resistance can be used as a high-accuracy MDR-TB index.

\section{Discussion}

Among the phenotypic methods available, the proportional method of drug resistance testing has a high sensitivity and specificity compared to other methods. But the only problem with the relative method is the relatively long time required to report the results $(26,27)$. Therefore, the use of molecular methods is very helpful in reaching a faster report. Among the molecular methods available, the GeneXpret MTB/RIF method is able to simultaneously identify the Mtb complex and its resistance to rifampin antibiotics directly from sputum collected within two hours. The accuracy, sensitivity, and specificity of this method are acceptable. The only drawback to using this method is the dependence on special cartridges that are necessarily imported from abroad (76-74). Therefore, it is recommended to launch another suitable molecular method with appropriate accuracy such as drug resistance evaluation using TaqMan Real Time PCR.

\section{Acknowledgment}

Noun

\section{Conflict of Interest}

Authors declared no conflict of interests. 


$$
\begin{aligned}
& \text { مجله ميكروبشناسى يزشكى ايران }
\end{aligned}
$$

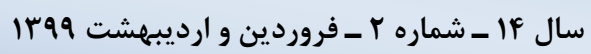

$$
\begin{aligned}
& \text { Journal homepage: www.ijmm.ir }
\end{aligned}
$$

مقاله

\title{
مرورى بر روش هاى فنوتيبى و زنوتيِى تشخيص مقاومتهاى دارويى در مايكوباكتريوم توبركلوزيس
}

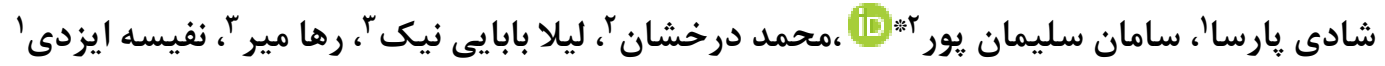

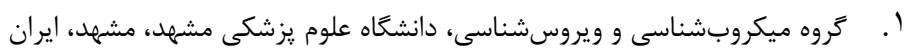

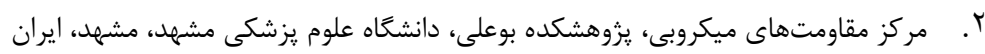

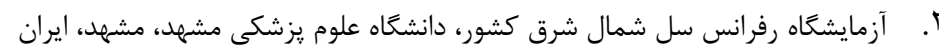

\section{جكيده}

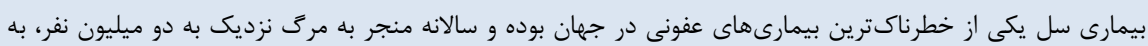

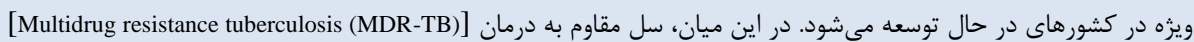

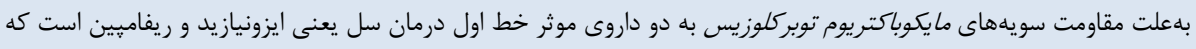

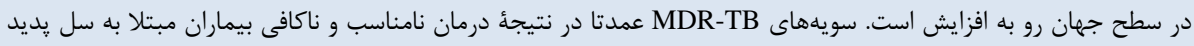

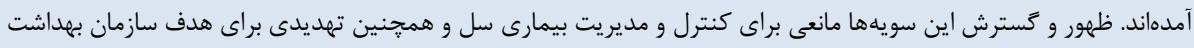

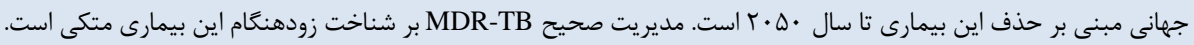

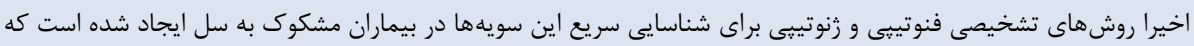

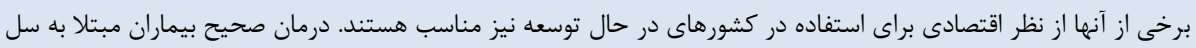

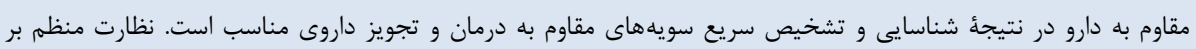

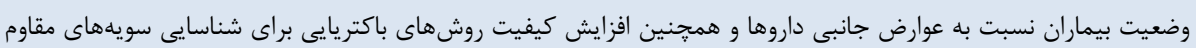

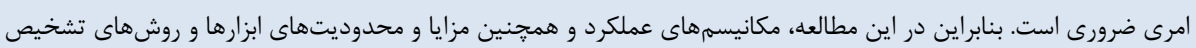

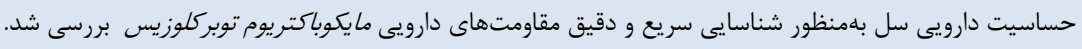
كليد وازهها: مايكوباكتريوم توبركلوزيس، مقاومت دارويى، MDR-TB، روش حساسيت دارويى. كجىرايت (] مجله ميكروب شناسى بزشكى ايران: دسترسى آزاد؛ كيى بردارى، توزيع و نشر براى استفاده غيرتجارى با ذكر منبع آزاد است.

اطلاعات مقاله

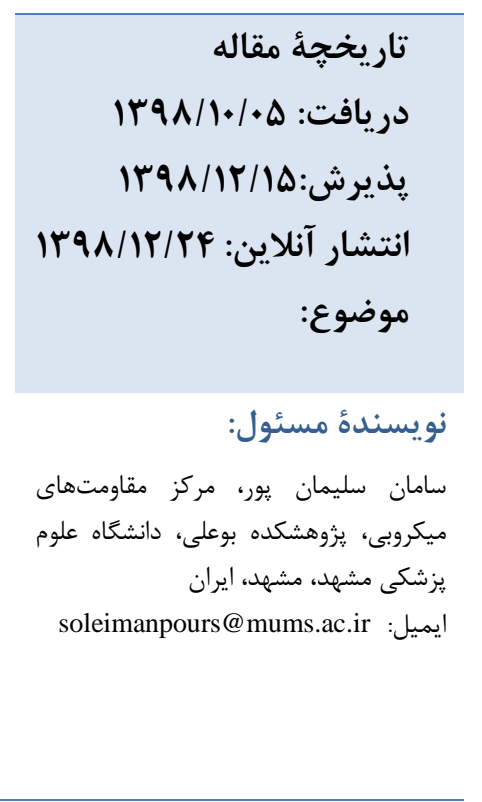

مقلدمه

دارويى' (MDR-TB) به صورت مقاومت به دو داروى موثر خط اول

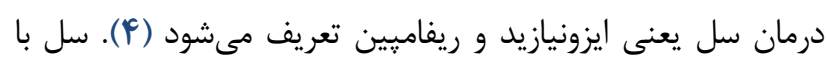

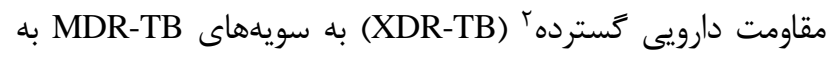
همراه مقاومت به تمامى فلئوركينولونهاى خوراكى و حداقل يكى از آمينوگليوزيدهاى تزريقى خط دوم درمان (آميكاسين، كايروئومايسين

$$
\text { و كانامايسين) كفته مىشود (ه). }
$$

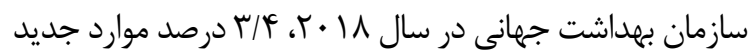
و I درصد موارد درمانشده قبلى مبتلا به MDR-TB و همجنين
بيمارى سل يكى از كشندهترين بيمارىهاى عفونى در جهان بوده و هنوز بهعنوان يك مسئله بهداشتى تهديد كننده سلامت جامعه يها

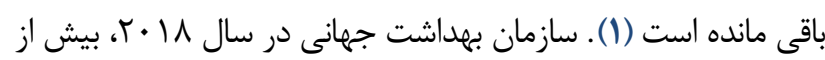

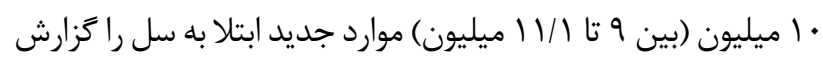

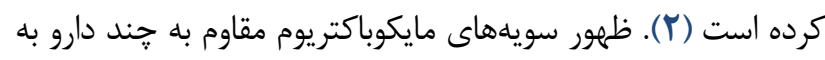
دليل عوامل مختلفى از قبيل إيدمى ايدز، استفاده نامنظم از داروهاى ضد سل، افزايش استفاده از داروهاى مخدر تزريقى و مهاجرت إيدمئ ازيل مناطق اندميك در حال افزايش است (Y). سل با مقاومت جند 
در تركيب با موتاسيون در زن katG مشاهده مىشود (سا, II) ساير

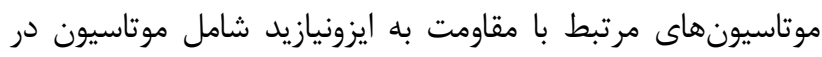

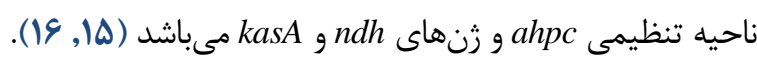

\section{ريفاميين: مكانيسم عملكرد و مقاومت}

ريفاميين يك آنتىبيوتيك با طيف اثر كسترده و باكتريسيدال است و از موثرترين داروهاى ضد سل به شمار مى آيد. ريفاميين

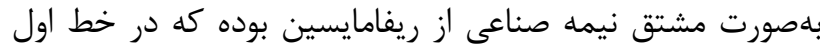

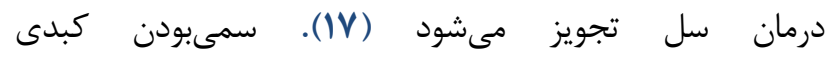
مهمترين عارضهُ اين دارو است و از اين رو افرادى (Hepatotoxicity) كه اين دارو را دريافت مى كنند ييوسته بايد تحت آزمايشهاى مربوط به كاركرد كبد قرار بخيرند (1)). مكانيسم اصلى عملكرد

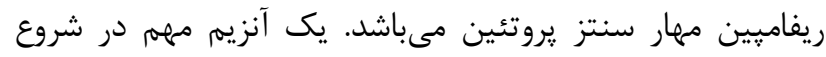

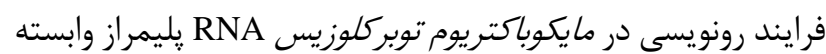
به DNA است. RNA يليمراز از جهار زير واحد آلفا، بتا، بتا يريم و و

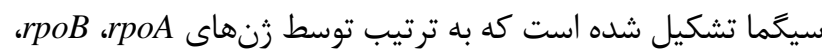
rpoD rpoC از آنزيم RNA يليمراز، سبب اختلال در طويلسازى زنجيره RNA

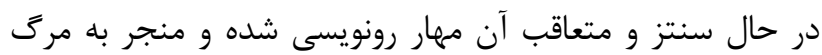
باكترى مىشود (•r). از آنجايى كه • • درصد سويههاى مقاوم به

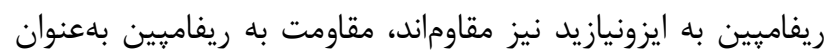
يك شاخص اصلى براى تشخيص MDR-TB به شمار مىرود (آب). بالغ بر ها درصد موتاسيونهاى مسئول مقاومت به ريفاميين

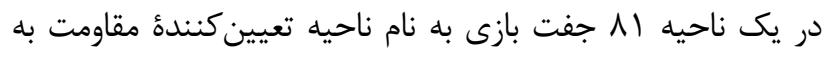

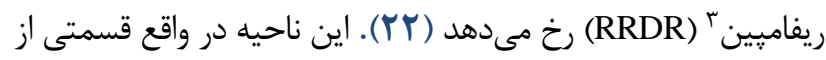

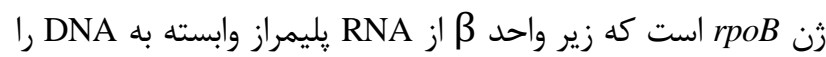

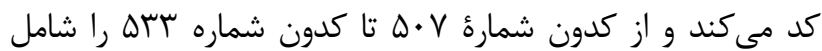

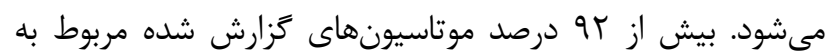

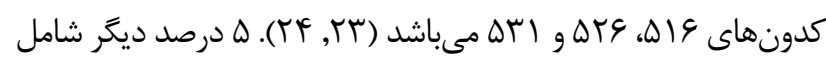
موتاسيون در ساير قسمتهاى زن rpoB و خارج از ناحيه RRDR

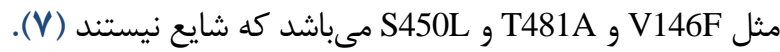

\section{روشهاى فنوتييى تشخيص سويههاى مقاوم به داروى سل (MDR-TB)}

تشخيص مقاومت دارويى در گذشته توسط روشهاى فنوتيبى

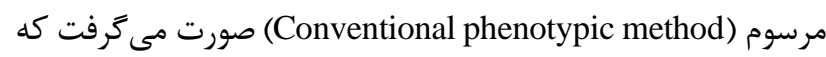

N/D درصد موارد MDR-TB همراه با XDR-TB را تخمين زده است

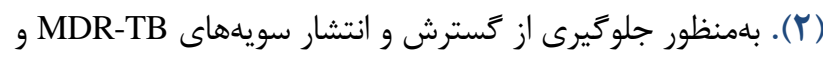
XDR-TB ساده، سريع و دقيق براى شناسايى مقاومت دارويى در بين بيماران مبتلا به سل امرى بسيار ضرورى است. بر خلاف بسيارى از باكترىها

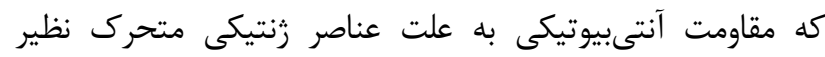

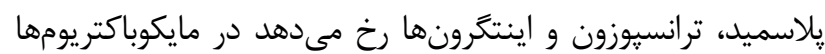
مقاومت دارويى بايئ كروموزومى دارد و اغلب ناشى از موتاسيونهايى

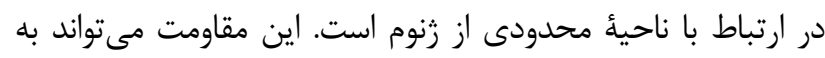

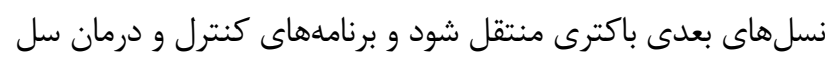

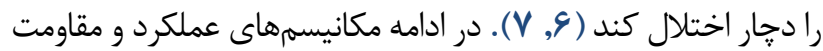
داروهاى ايزونيازيد و ريفاميين و همجنين مزايا و محدوديتهاى ابزارها و روشهاى تشخيصى حساسيت دارويى سل بلمنظور معرفى

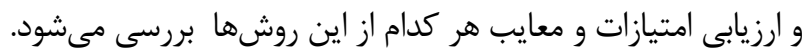

\section{ايزونيازيد: مكانيسم عملكرد و مقاومت}

Hydrazide ايزونيازيد يا هيدرازيد نيكوتينيك اسيد

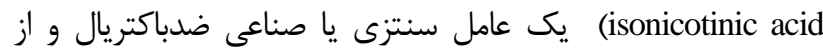

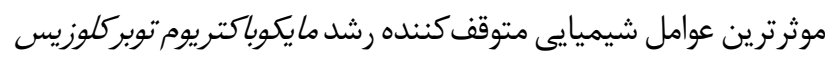
است (1). ايزونيازيد بلهورت ييش دارو بوده و فعال سازى آن بهوسيلة

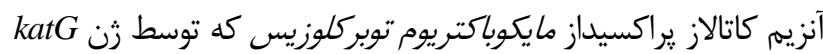

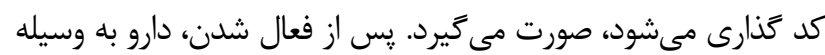

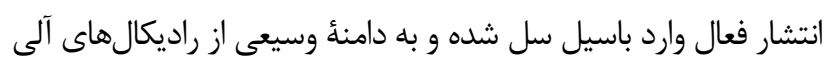
و كونهاى اكسيرن غيرفعال تبديل مىشود (9). مكانيسمى كه بهطور وسيعترى بذيرفته شده است دلالت بر آن دارد كه عملكرد ايزونيازيد

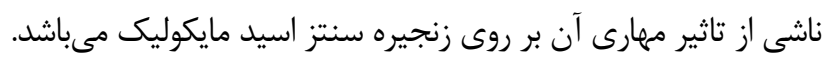

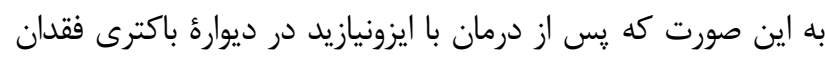

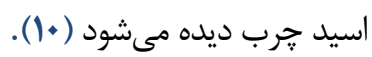

مقاومت به ايزونيازيد ناشى از جهشهاى نقطهاى است.

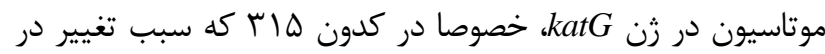

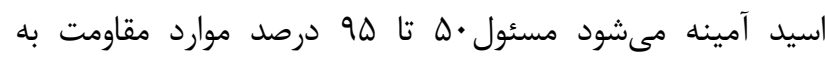
ايزونيازيد است (II, r|). ديخر موتاسيون كمتر شايع در ناحيه يروموتورى inhA كه كد كننده enoyl-ACP ردوكتاز مىباشد مشاهده

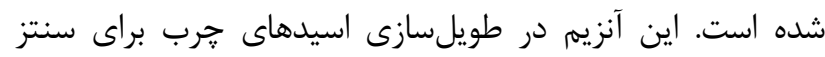

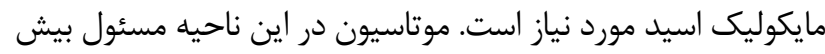

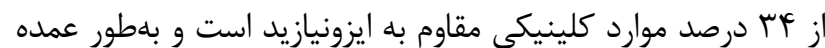


حضور آنتىبيوتيكهاى مورد نظر صورت مى گيرد (جدول ()). اين

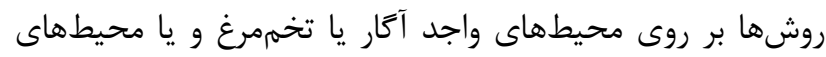

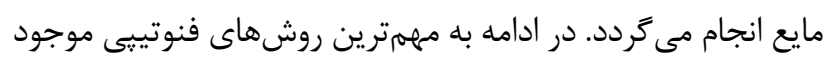

اشاره خواهد شد.
اكثر اين روشها يرزحمت و وقت گير بودند. در سالهاى اخير روشهاى فنوتييى جديد و زنوتييى براى تشخيص مقاومتهاى ورئ

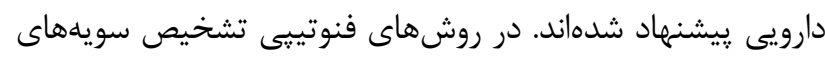

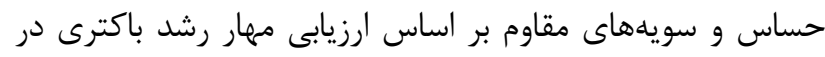

جدول ا. مقايسٔ روشهاى فنوتيبى تعيين حساسيت آنتى بيوتيكى در ارزيابى مقاومت دارويى مايكوباكتريوم توبركلوزيس

\begin{tabular}{|c|c|c|c|}
\hline 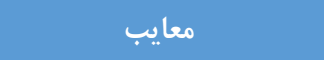 & 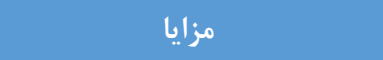 & 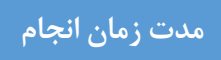 & روشها \\
\hline \multicolumn{4}{|c|}{ 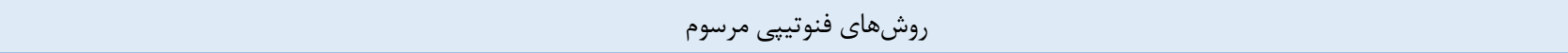 } \\
\hline \multicolumn{4}{|c|}{ محيط جامد (محيط لون اشتاين-جانسون يا محيط ميدل بروى 7H10/11) } \\
\hline \multirow{3}{*}{ ير زمانبر } & \multirow{3}{*}{ 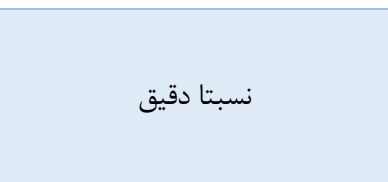 } & \multirow{3}{*}{ جم-1 آ هفته از زمان } & روش برويورشنال \\
\hline & & & 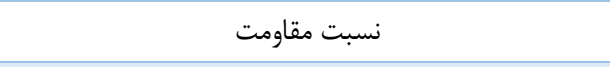 \\
\hline & & & 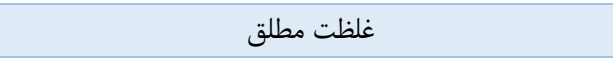 \\
\hline \multicolumn{4}{|c|}{ محيط مايع } \\
\hline \multirow{3}{*}{$\begin{array}{c}\text { به يروتكل ايمنى يرتوى نياز } \\
\text { زحمت زياد در زمان تلقيح } \\
\text { نمونه }\end{array}$} & قابل دسترس بلصورت كيت تجارى & \multirow{3}{*}{ جمع V- لمفته آز زمان } & (راديومتريك) BACTEC 460 TB System \\
\hline & 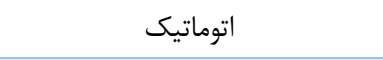 & & BACTEC MGIT 960 TB System \\
\hline & اتوماتيك & & VersaTREK \\
\hline \multicolumn{4}{|c|}{ روشهاى فنوتيبى سريع } \\
\hline 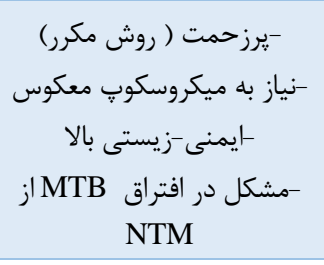 & 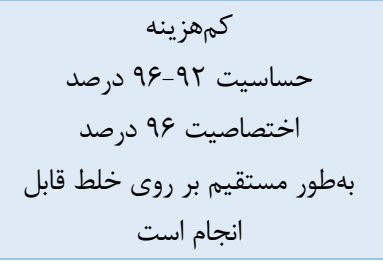 & جمعآ هفته از زمان & MODS \\
\hline -ايمنى-زيستى بالا & 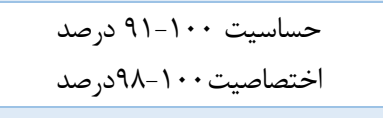 & 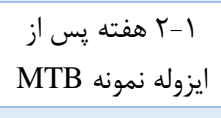 & روش رنَى سنجى \\
\hline 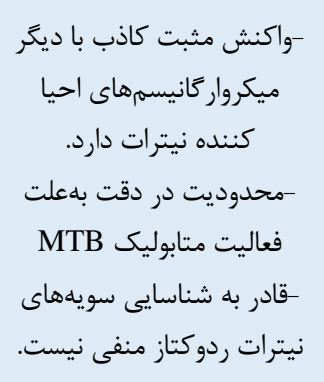 & 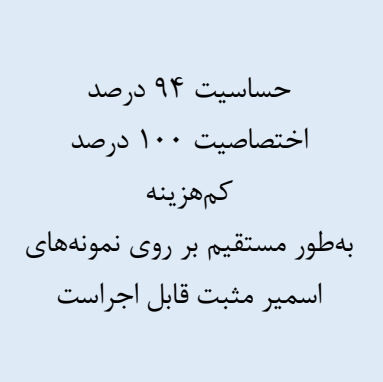 & جمع آورى نمته از زمان & 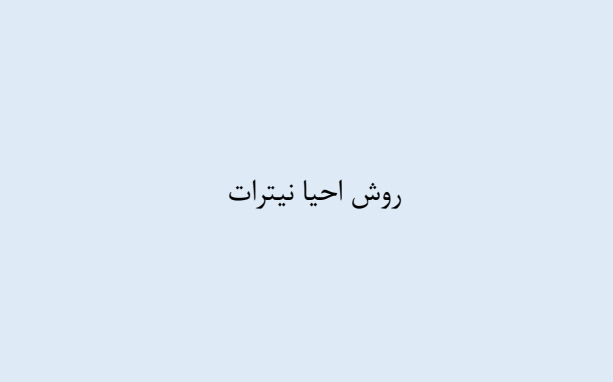 \\
\hline
\end{tabular}

سميوزيومهاى سازمان جهانى بهداشت و اتحاديه بينالمللى عليه سل سه روش قابل قبول براى مقاومت دارويى سلى سل ران بان تعريف

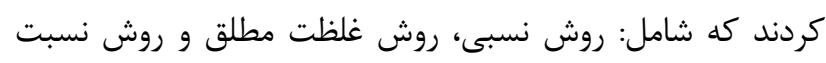

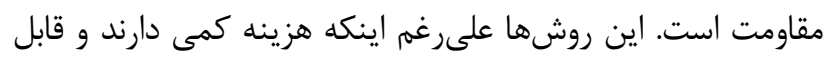

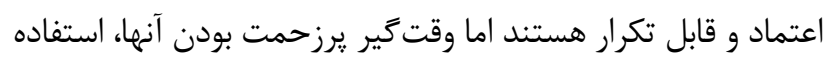
از اين روشها را با محدوديت روبرو كرده است.
روش هاى فنوتيبى مرسوم بر روى محيط جامد

رايجترين محيط هاى كشت مورد استفاده بر پايه تخمم مرغ

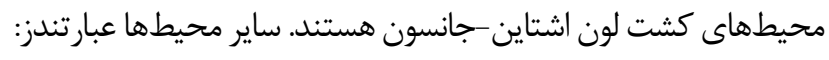

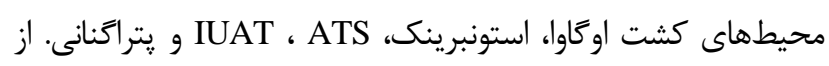

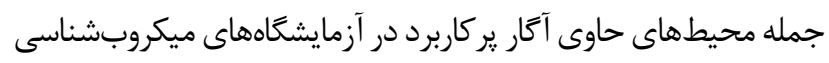

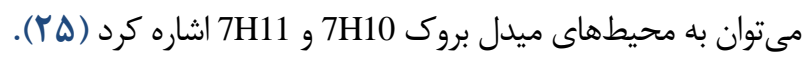




\section{روش نسبت مقاومت}

اين روش مشابه روش غلظت مطلق مى باشد و عبارت است از

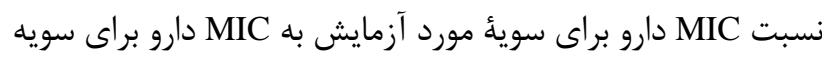

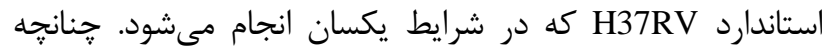

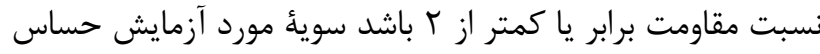

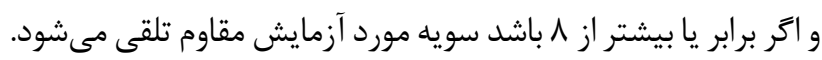

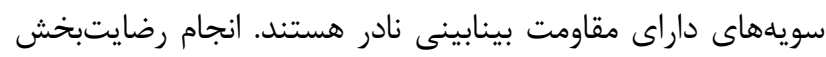

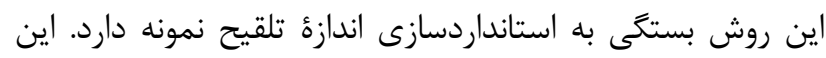

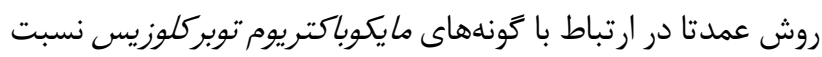

به ديكر گونههاى مايكوباكتريوم به كار مىرود ( (ץ).

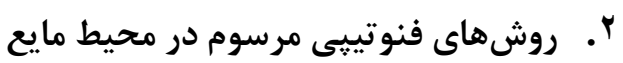

استفاده از محيطهاى مايع به جاى محيطهاى جامد سبب

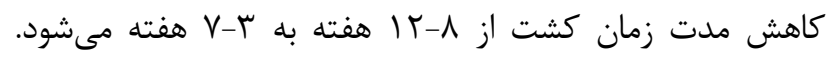

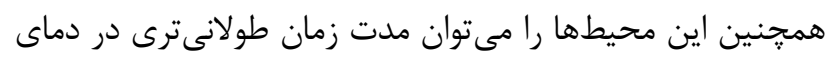

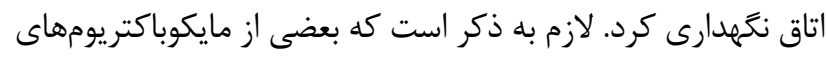

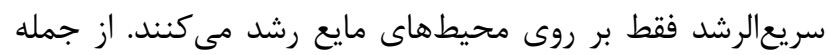

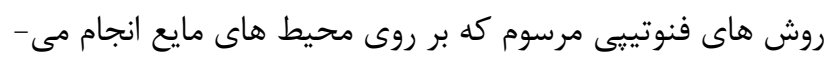

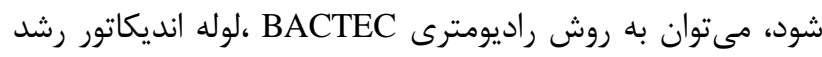

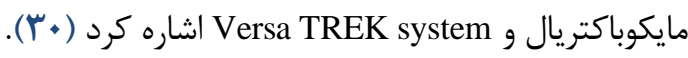

\section{روش راديومتريك BACTEC 460 TB SYSTEM}

محيط كشت مورد استفاده در روش راديومترى محيط

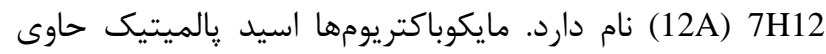

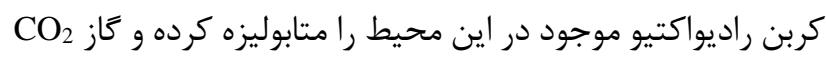

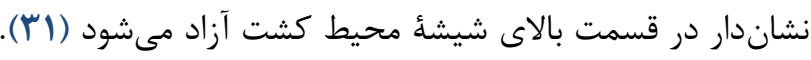
اين كاز توسط دستكاه نيمه اتوماتيكى به نام

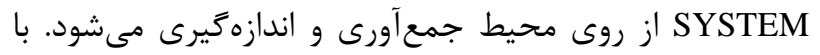

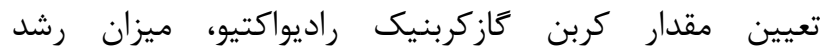

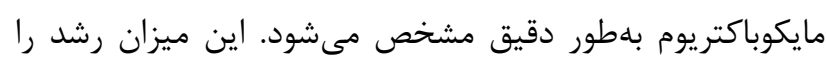

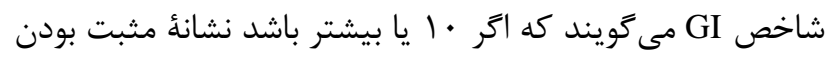

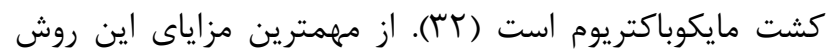

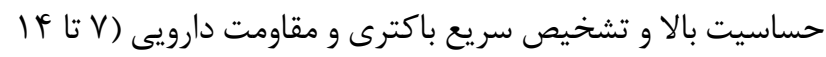

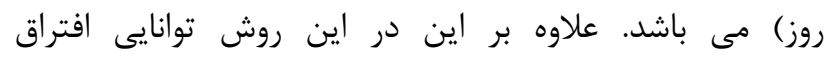

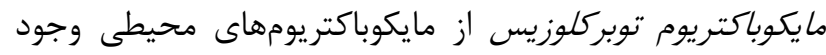

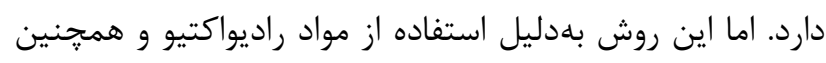

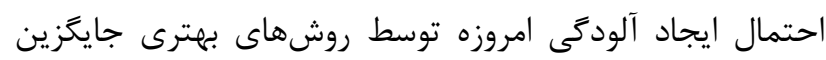

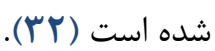

\section{(Proportional) ( روش نسبى)}

روش نسبى معمولترين روش مورد استفاده در سرتا سر جهان است. اساس اين روش تهيئ رقتهاى متوالى از سوسيانسيون

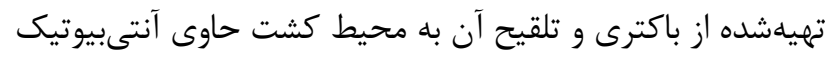

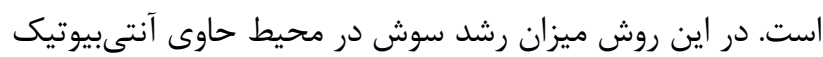

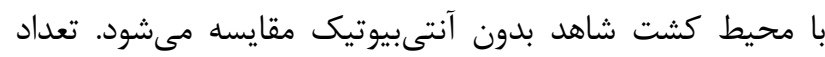
كلنىهاى شمارش شده در لولأ كنترل (فاقد آنتىبيوتيك) نشاندهندة تعداد باسيل زنده در تعداد كل ميكروب كشت شده

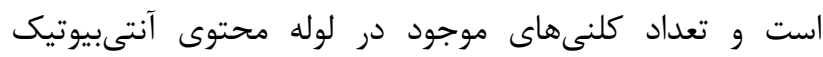
نشاندهندة تعداد باسيلهاى مقاوم در همان تعداد ميكروب است. نسبت عدد اول به عدد دوم را نسبت بحرانى يا درصد مقاومت كَويند

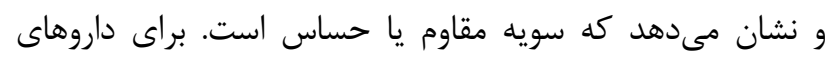

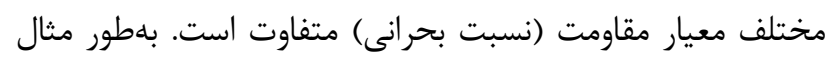
درصد مقاومت براى دو داروى ايزونيازيد و ريفامِين ا درصد است.

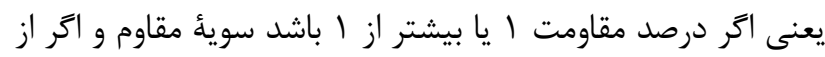

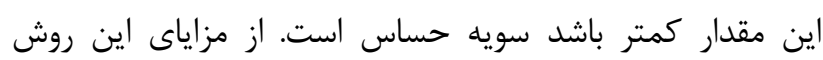

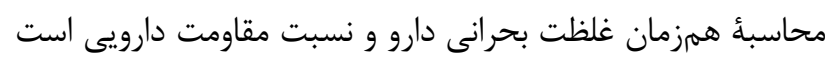

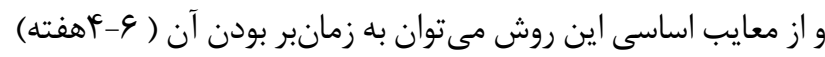

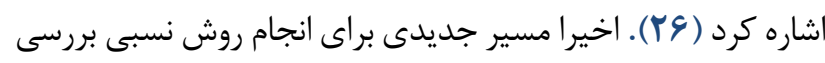

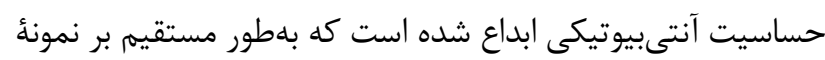
خلط قابل انجام است. در يك مطالعه Amini و همكاران نشان دادند كه روش نسبى مستقيم (Direct proportional method) در محيط

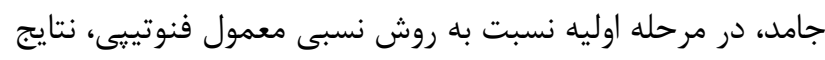

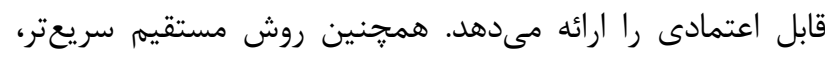

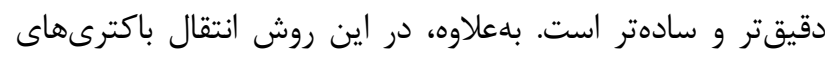

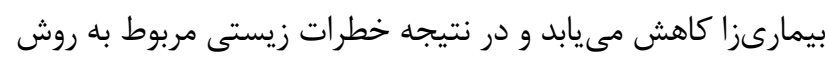
نسبى معمولى كاهش مى يابد (YV)

\section{روش غلظت مطلق}

در روش غلظت مطلق، ميزان استانداردى از باكترى در محيط

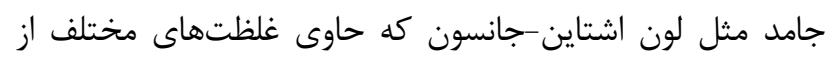

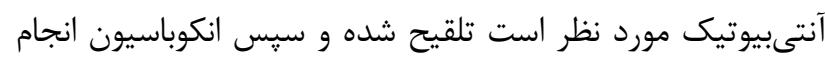

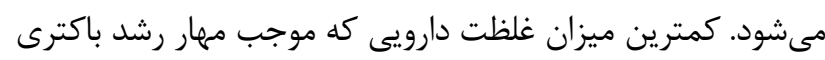

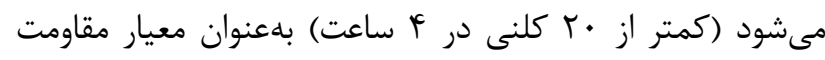

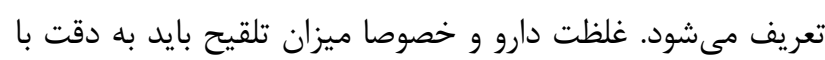

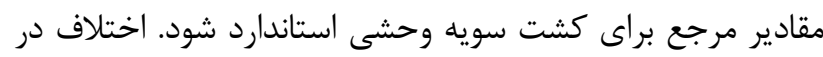
ميزان تلقيح بيشترين عامل خطا در اين روش است است و در در نتيجه

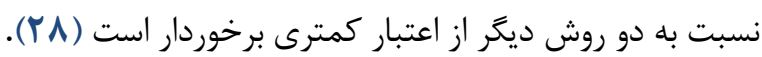


از آلودگى به فاز قابل تشخيص است. در سويههاى مايكوباكتريوم

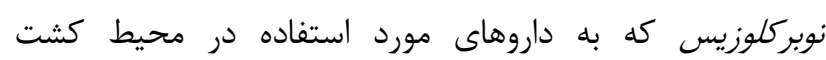

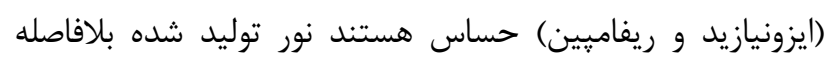

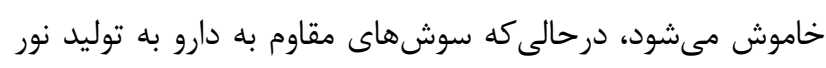

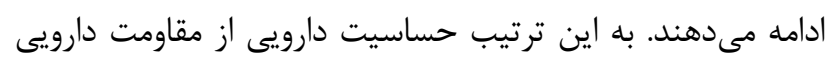

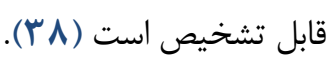

\section{روش رنگ سنجى Colorimetric methods}

روش ديخر براى تشخيص سويههاى Mtb مقاوم به درمان

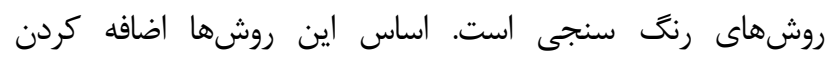

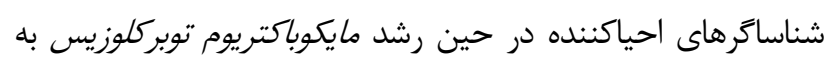

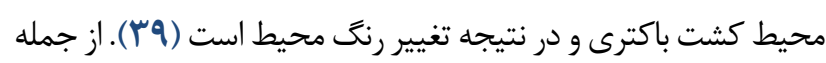

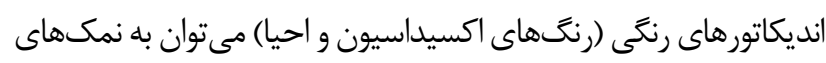

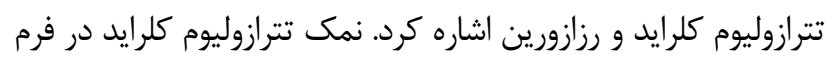
اكسيده خود زرد رنغ است ولى در طى رئ رشد باكترى مايكوباكتريوم

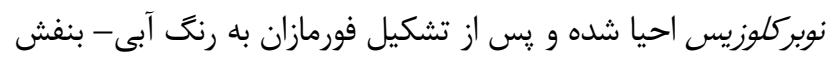

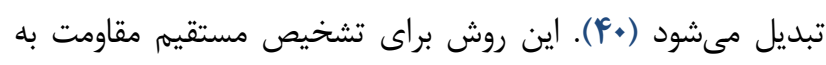

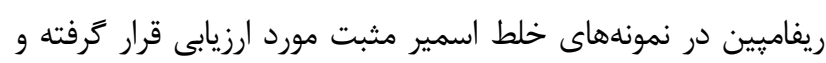

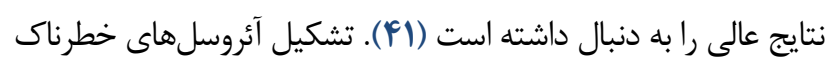

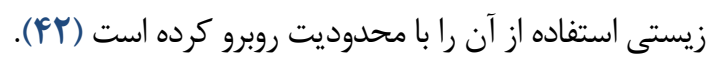

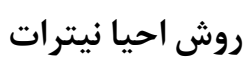

اساس اين روش احياى نيترات به نيتريت توسط مايكوباكتريوم

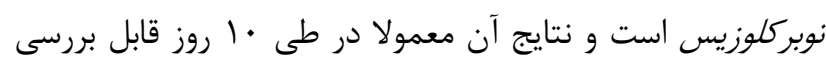

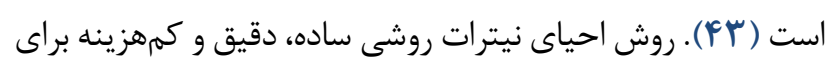
تشخيص سويههاى MDR-TB است و در مورد نمونههاى خلط

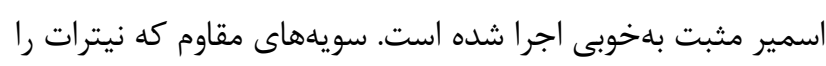

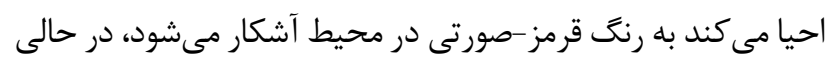

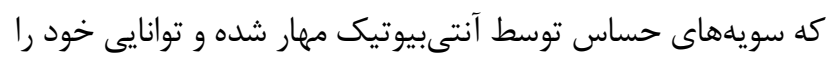

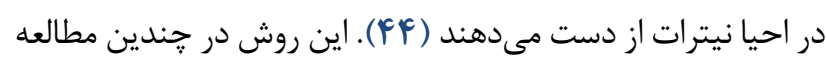

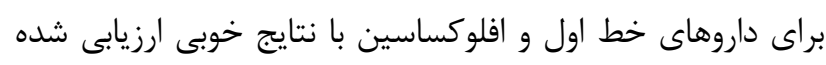

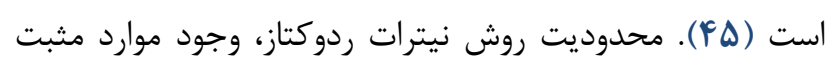

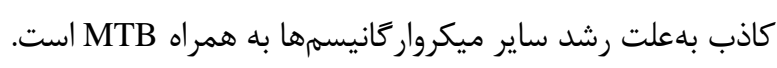

\section{روش هاى زنوتيِى تشخيص سويههاى مقاوم به} داروى سل (MDR-TB)

روشهاى مولكولى توانايى تشخيص زنهاى موثر در ايجاد

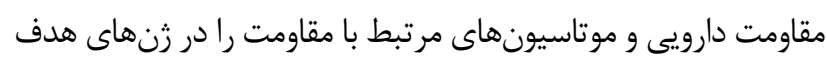

\section{روش لولئ انديكاتور رشد مايكوباكتريال MGIT} همانطور كه در بالا اشاره شد، امروزه سيستمهاى

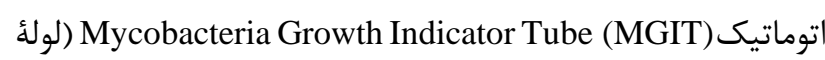

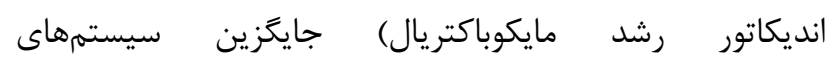

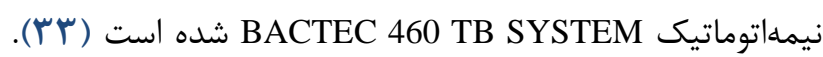

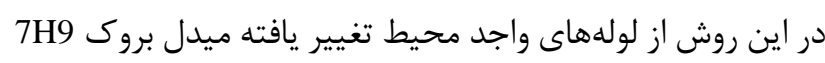

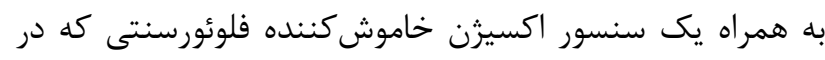

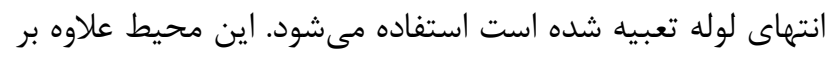

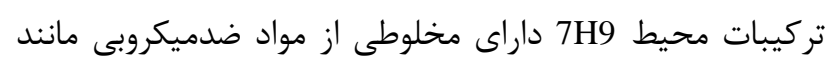
PANTA ترىمتويريم و آزلوسيلين) بهمنظور جلوكيرى از رشد باكترى إنهاى

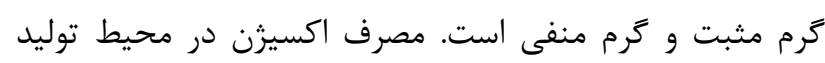

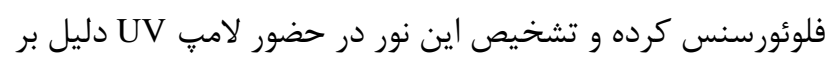

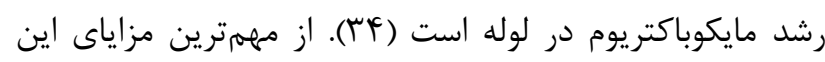

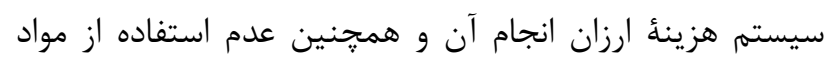

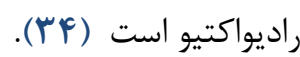

\section{روش Versa TREK}

يكى ديكر از روشهاى اتوماتيك بر بائُ محيط مايع سيستم

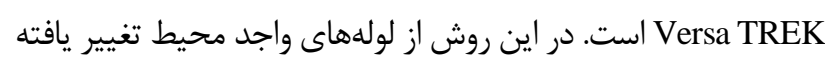

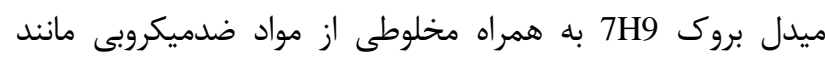
PVNA

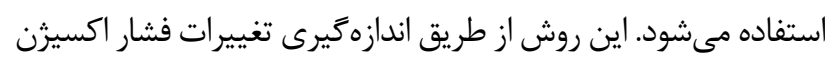

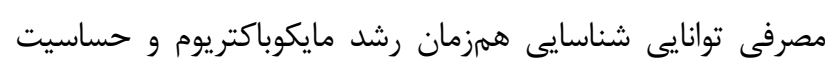

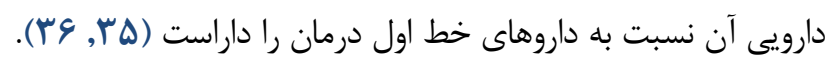

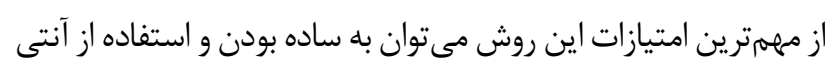

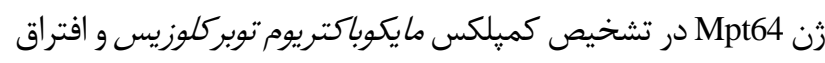

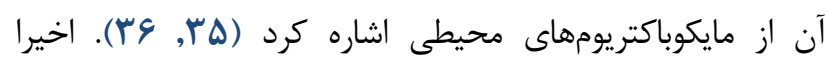

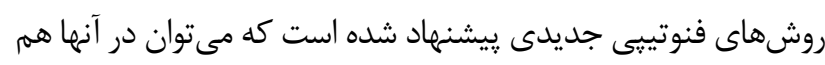

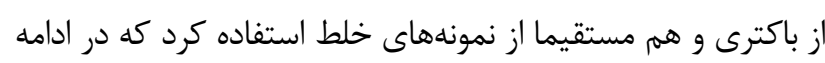
به توضيح مختصرى از آنها يرداخته خواهد شد.

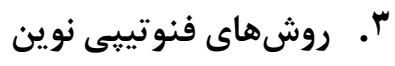

\section{روش مايكوباكتر يوفاز بيانكر لوسى فراز}

اين روش بر اساس فاز و براى شناسايى سريع مايكوباكتريومها

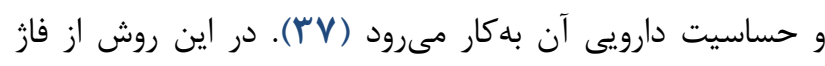

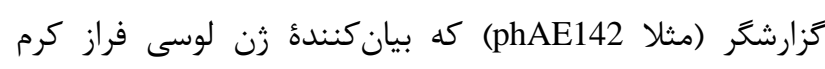

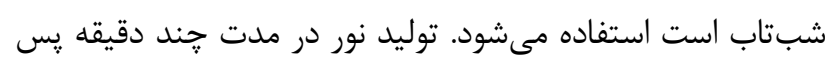


از جمله اين روشها مىتوان به موارد زير اشاره كرد:

مايكوباكتريوم توبركلوزيس دارند. با استفاده از اين روشها نتايج ظرف

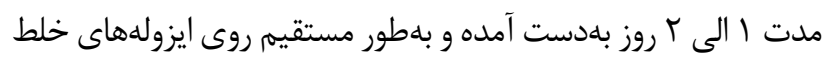

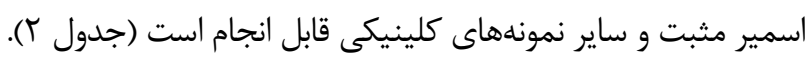
جدول r. مقايسٔ روشهاى زنوتيبى تعيين حساسيت آنتىبيوتيكى در ارزيابى مقاومت دارويى مايكوباكتريوم توبركلوزيس

\begin{tabular}{|c|c|c|c|}
\hline معايب & 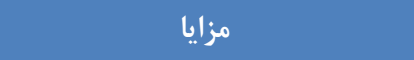 & زمان انجام & روشها \\
\hline احتمال شناسايى جهشهاى خاموش & سرعت و دقت بالا & 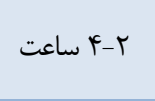 & $\begin{array}{l}\text { Amplification refractory } \\
\text { mutation system (ARMS) }\end{array}$ \\
\hline ناتوانى در افتراق جهشهاى خاموش از جهشهايى كه & سرعت و دقت بالا & 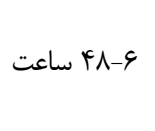 & $\begin{array}{c}\text { Line probe assay } \\
\text { - INNO-LipA® Rif.TB } \\
\text { - Genotype®MTBDR plus }\end{array}$ \\
\hline 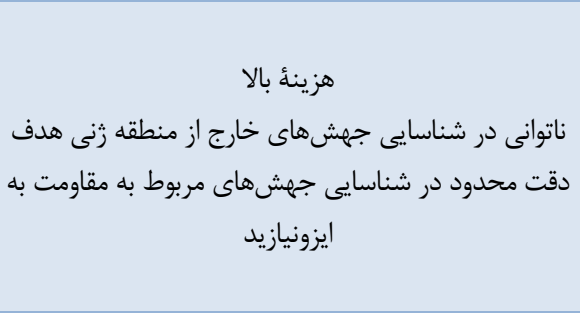 & 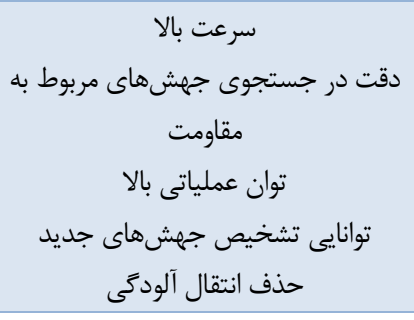 & 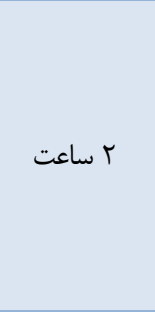 & RT-PCR \\
\hline 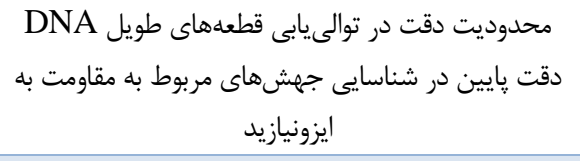 & $\begin{array}{l}\text { ارائه توالى دقيق توان عملياتى بالا } \\
\text { DNA }\end{array}$ & ( & Pyrosequencing \\
\hline 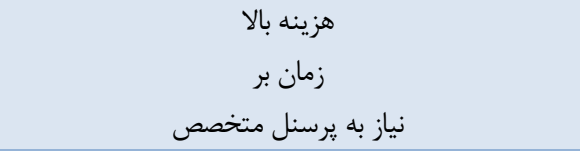 & روشى استاندارد طلايى براى شناسايى ماسيون مربوط مقاومت & & DNA-Sequencing \\
\hline 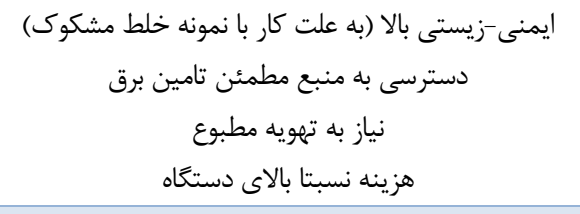 & حساسيت و اختصاصيت بالا & 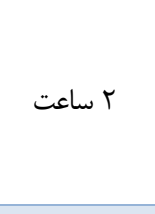 & Xpret MTB/RIF (cephied) \\
\hline احتمال شناسايى جهشهاى خاموش & سرعت و دقت بالا & 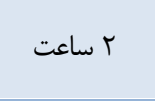 & High Resulation Melt \\
\hline
\end{tabular}

كار مى كند. يرايمر ديخر با همان يرايمر مشترك، قطعهاى بزرگتر

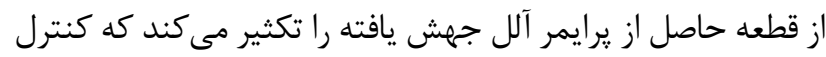
داخلى واكنش است. فقدان يا حضور قطعه كوتاهتر نشان دهندة وجود يا عدم وجود آلل جهش يافته است. در واقع ARMS-PCR

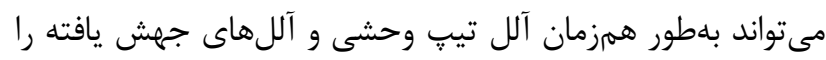

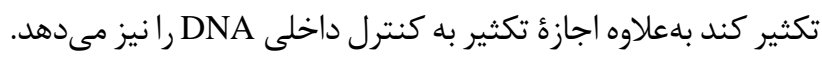

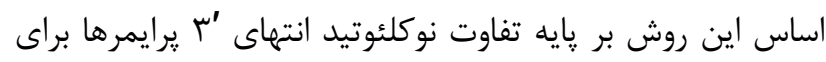

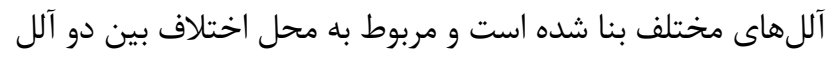
است كه سبب افتراق در تكثير محصول مىشود. لازم به ذكر است

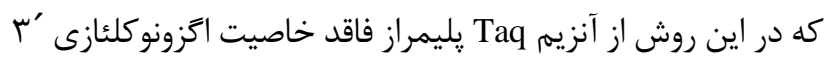

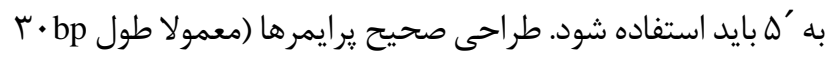
انتخاب مىشود) و دماى ذوب بالاى آنها سبب جلوخيرى از نتايج Amplification refractory mutation
system (ARMS)

يك روش ساده و سريع براى شناسايى ARMS-PCR

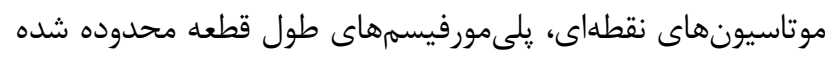
و يا حذف شدن كوجك در طول توالى قطعه DFLP) PCR و (F) و اين روش همجنين PAllele-specific PCR amplification of specific alleles (PASA) اين روش در واقع كاربردى از PCR است كه در آن DNA توسط

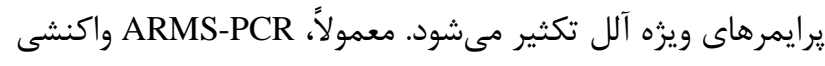

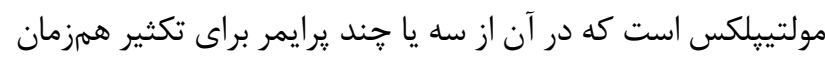

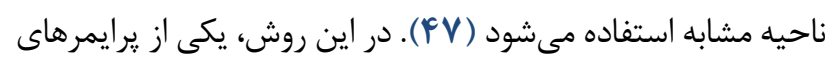

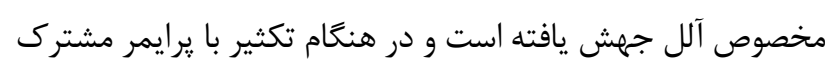


يلى آكريل آميد غير دناتوره قرار مى گيرد. در شرايط غير دناتوراسيون،

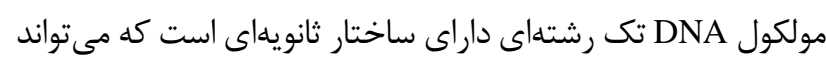

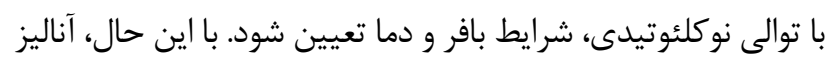

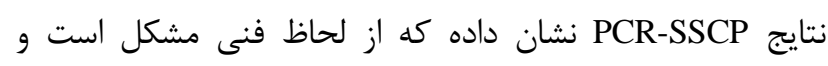

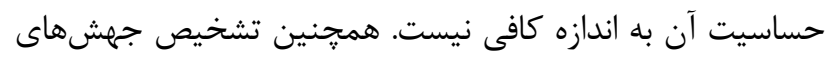

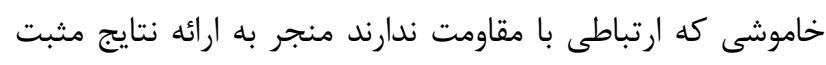

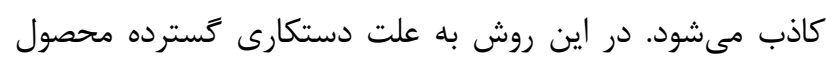
PCR

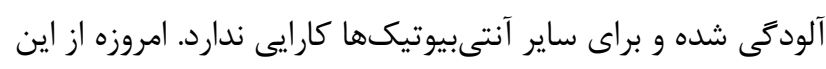

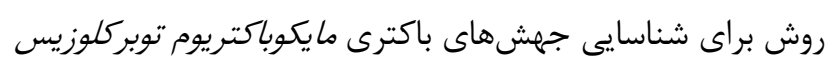

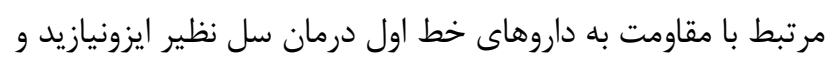

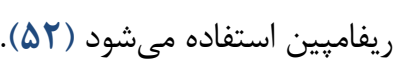

\section{צCR-restriction fragment length روش polymorphism}

روش PCR-restriction fragment length polymorphism

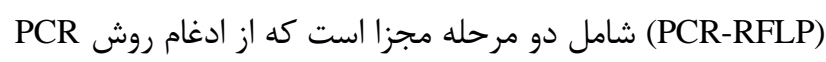

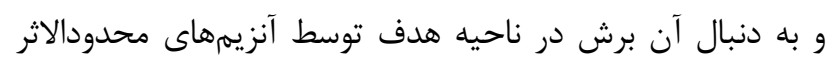
تشكيل شده است. روش PCR-RFLP روشى ساده، سريع و ارزان

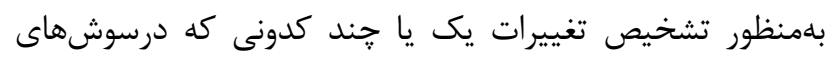

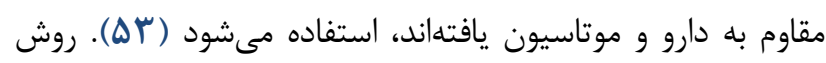

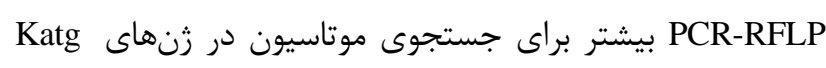

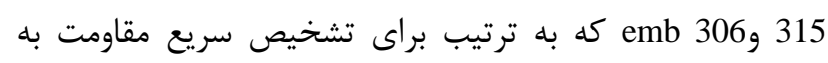

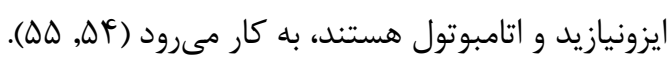

\section{•. روش تعيين حساسيت آنتى بيوتيكى با Real Time}

PCR

روش Real Time PCR بسيار شبيه به روش PCR معمولى

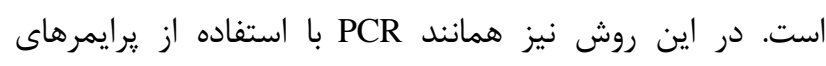

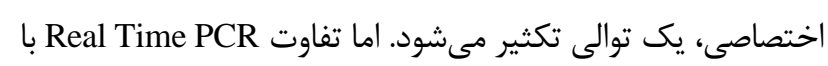

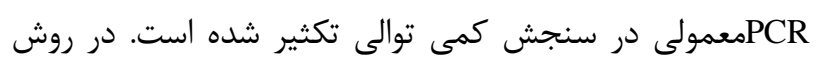

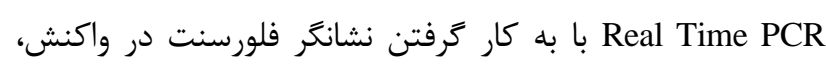

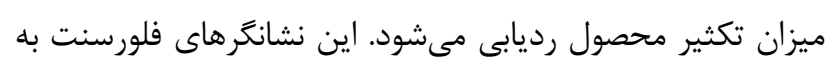

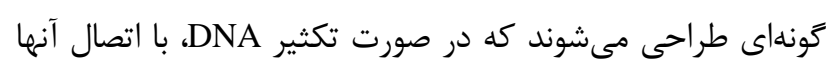
به به نور توليد كنند. روش Real Time PCR به دو دسته تقسيم

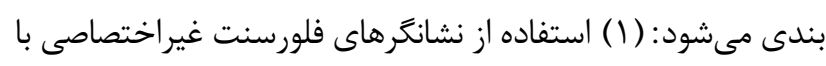

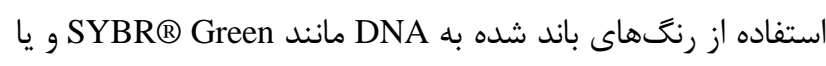
(r) Eva green استفاده از شناساكرهاى (يروب) زن هدف. در اين روش از تعدادى إنى
نادرست مى گردد. افزايش تعداد سيكلهاى غير ضرورى منجر به

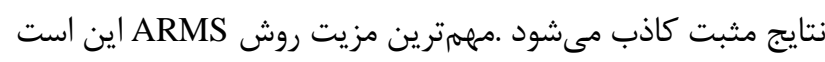

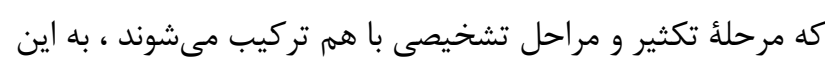

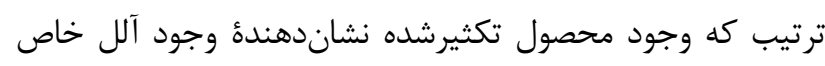

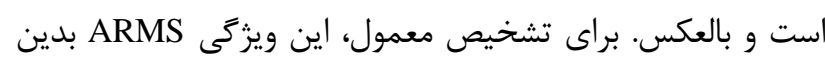

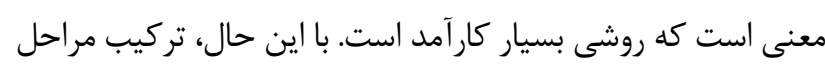

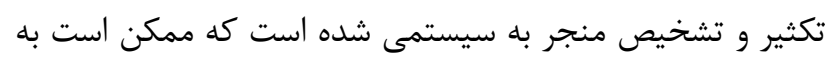

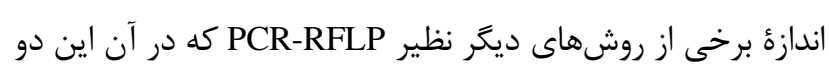

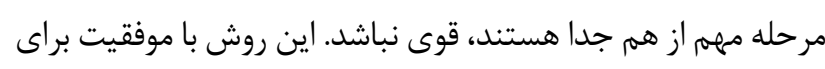
تشخيص جهشهاى مرتبط با مقاومت به ريفامِين در مايكوباكتريوم

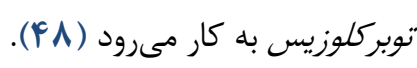

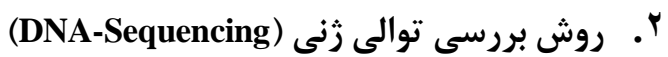

تعيين توالى DNA گَستردهترين روش زنوتيجى براى تشخيص

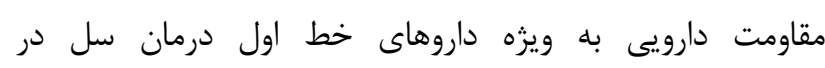

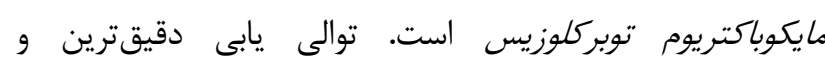

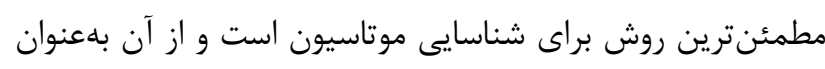

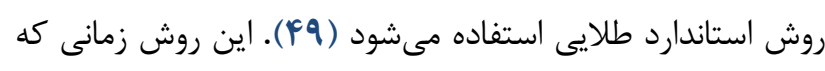

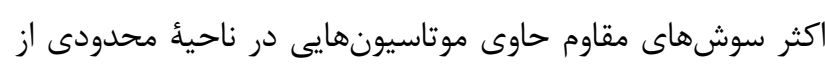

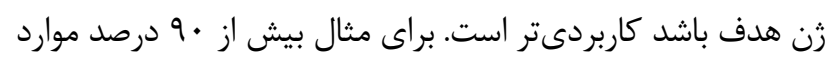

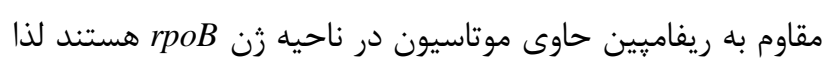

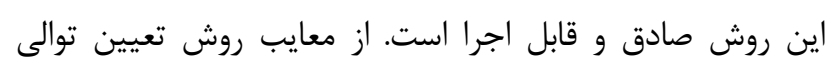

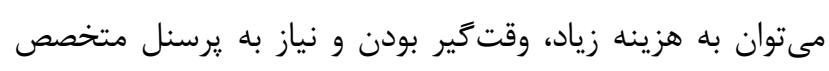

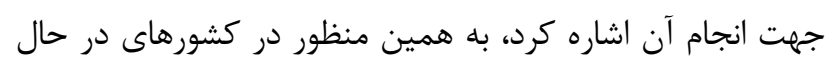
توسعه بهطور معمول در دسترس نيست و نمى توان از از آن بلهعنوان روشى براى غربالكرى موتاسيونها استفاده كرد (•ه) .

\section{r.r PCR-Single Stranded Conformation} Polymorphism Analysis (SSCP)

روش PCR-SSCP روشى ساده و سريع است كه مى تواند براى

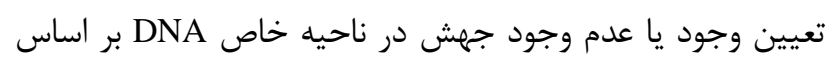

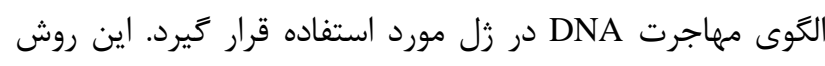

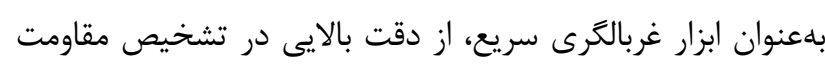

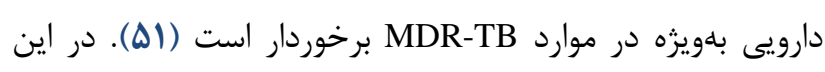

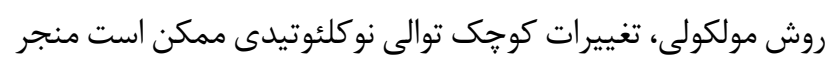

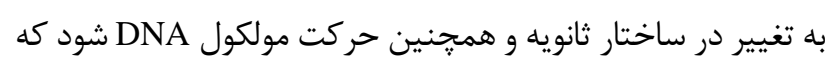

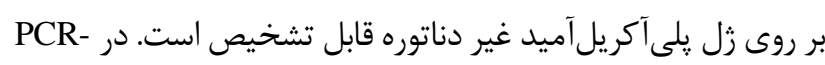

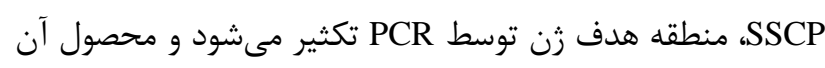

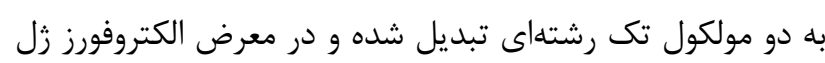


ساير روشهاى تعيين زنوتيب نظير توالىيابى و و TaqMan SNP

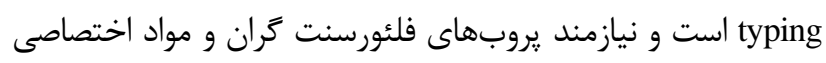

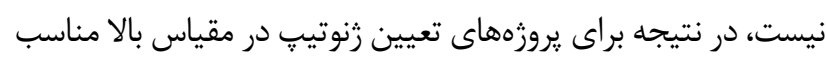

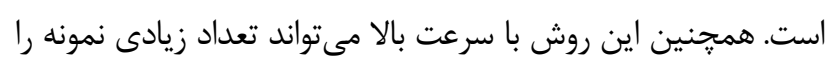

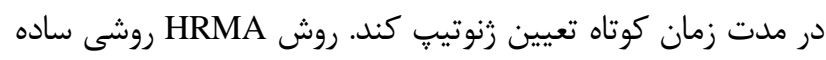

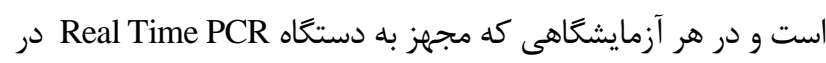

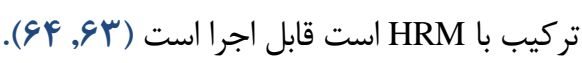

از محدوديتهاى اين روش احتمال شناسايى جهشهاى

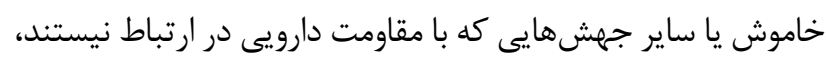

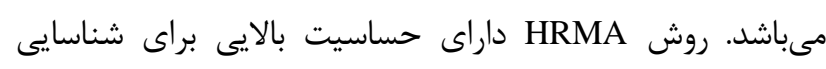

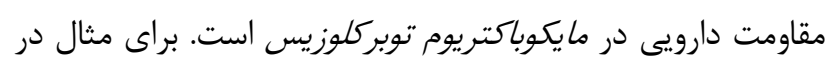

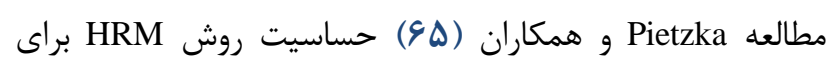

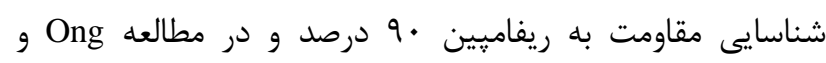

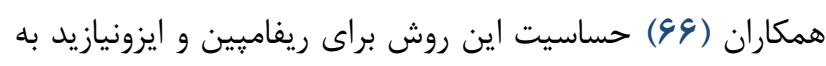

ترتيب 9 درصد و 91 درصد كزارش شده است (94) (9).

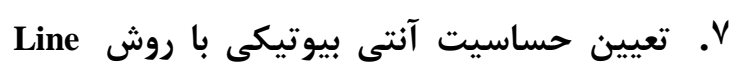
probe assay (LiPA)

سنجش يروب خطى (Line probe assay) روشى مبتنى بر است كه شامل استخراج DNA Strip Test

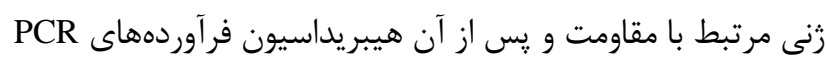

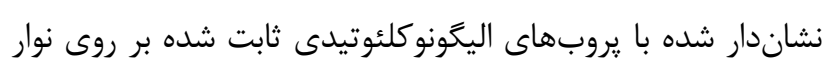

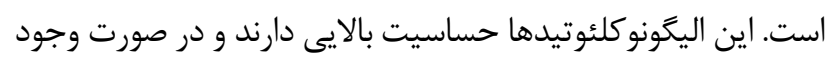

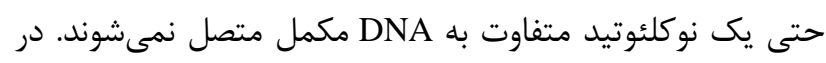

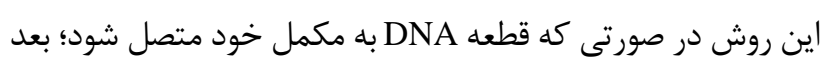

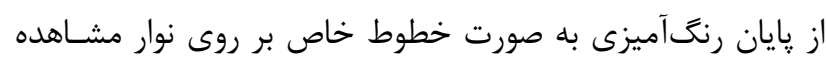

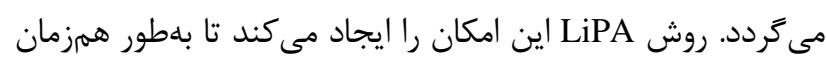

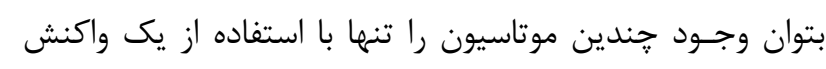

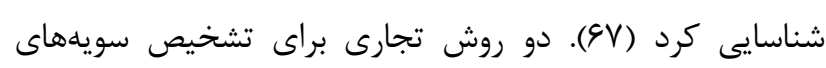
MDR-TB براساس اين روش وجود دارد:

\section{روش INNO-LiPA Rif. TB (Innogenetics)}

اين روش موتاسيونهاى مربوط به مقاومت به ريفاميين را در

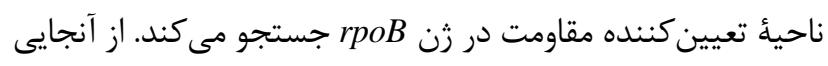

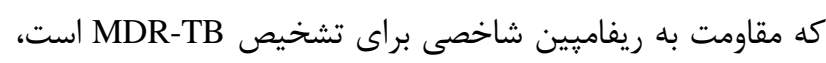

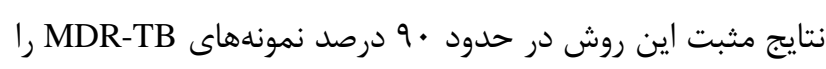

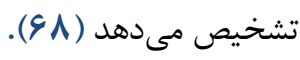

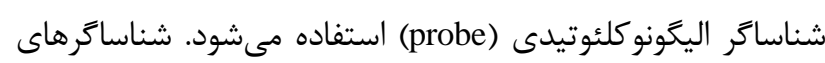

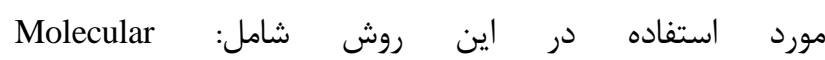
و FRET Hybridization Probes ،TaqMan® Probes ،Beacons TaqMan® هستند كه از ميان آنها سه روش Scorpion® Primers

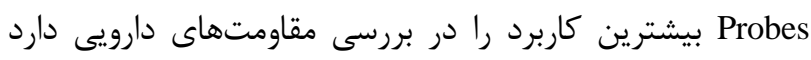

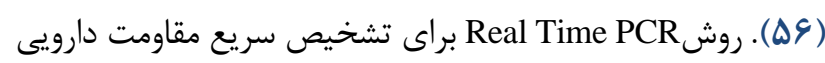

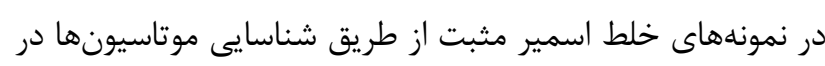

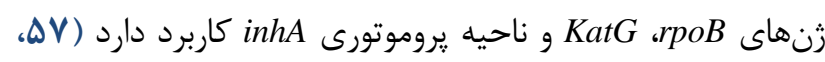
RT-PCR . (DA

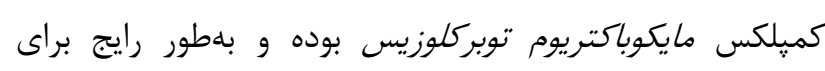

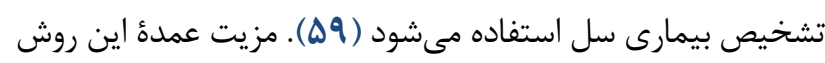

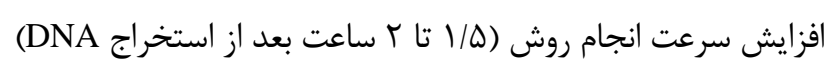

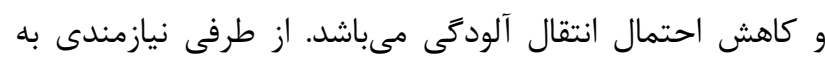

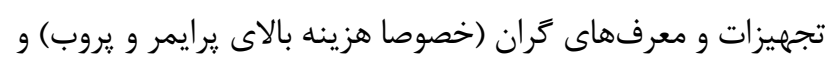

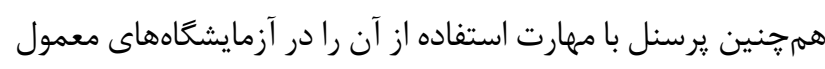

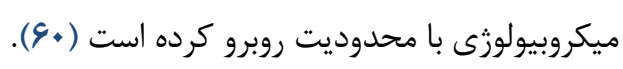

\section{لا. تعيين حساسيت آنتىبيوتيكى با روش High}

\section{Resolution Melt-HRM}

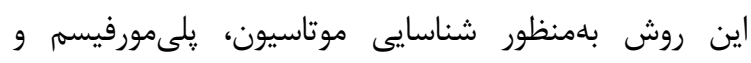

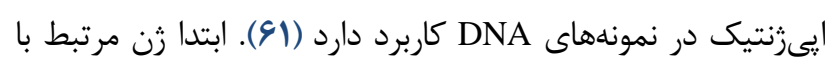

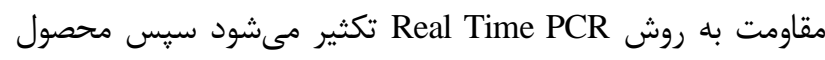
SYBR در حضور رنخ فلئورسنت اختصاصى DNA PCR Eva Green ،Green

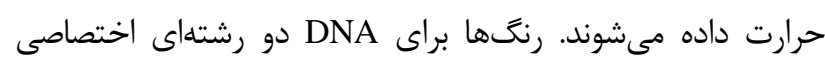

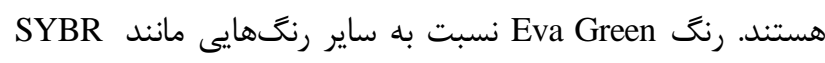
Green

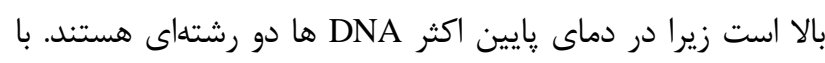

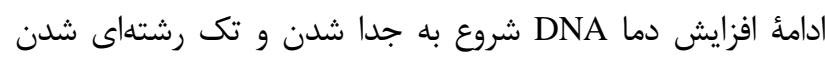

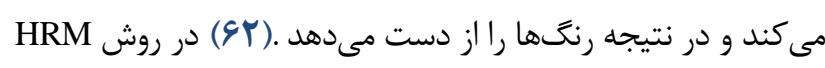

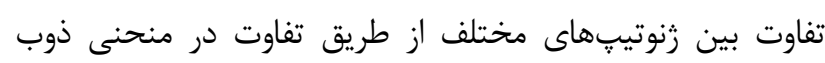

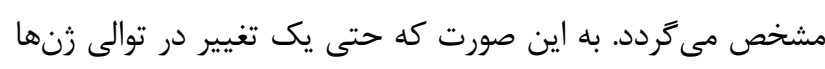

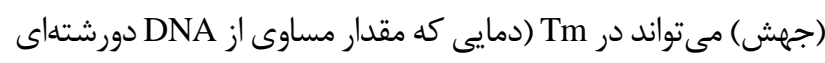

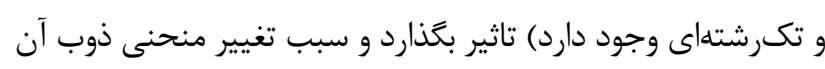

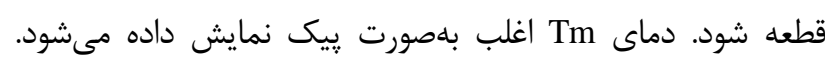
نمونههاى رفرانس بايد پيك يكسان در Tm مورد انتظار داشته باشند

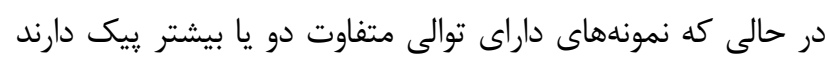

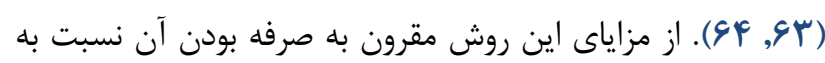


توبركلوزيس (MTBC) و مقاومت آن به آنتىبيوتيك ريفامِين را بلهور مستقيم از خلط جمع آورى شده در عرض دو دو ساعت شناسايى

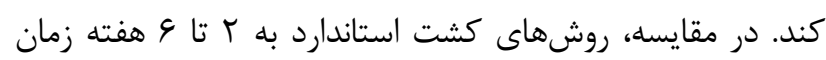

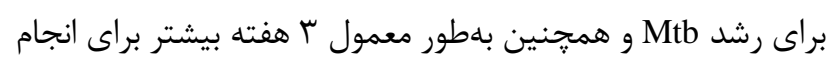

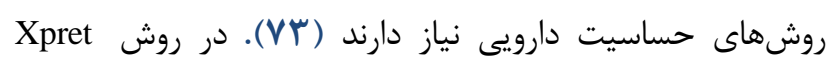

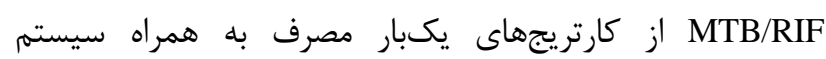
GeneXpret

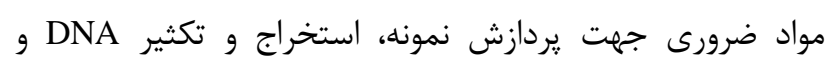

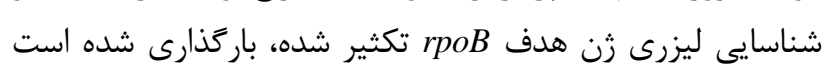
(VF)

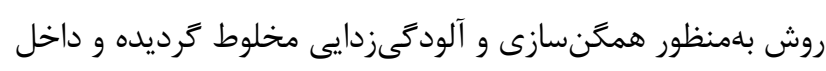

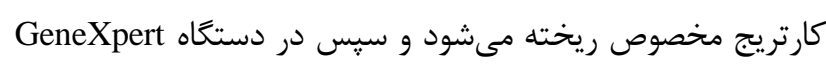

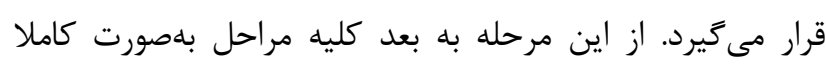

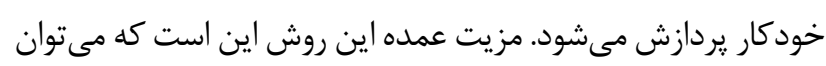
آن را بهطور دقيق با حداقل زمان انجام داد. حساسيت (حدود

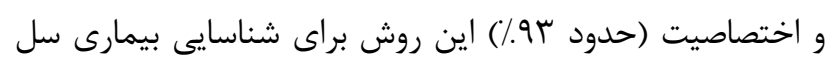

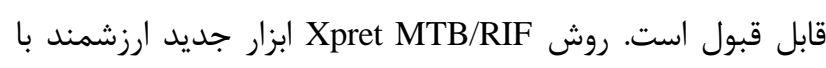

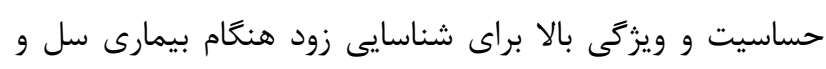

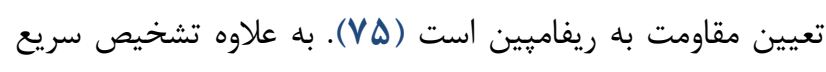

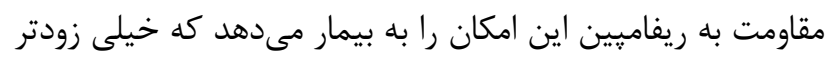

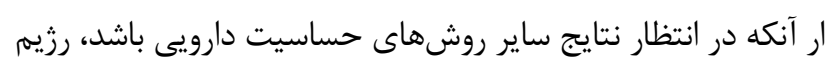

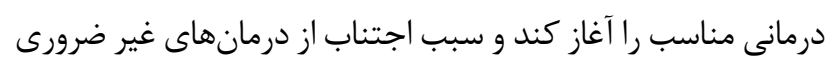

$$
\text { و صرفهجويى در هزينهها مىشود (V) (V). }
$$

\section{بحث}

شيوع بالاى سل مقاوم به درمان (MDR-TB) بهعنوان بيمارى عفونى خطرناك و كشنده، در نتيجه عدم وجود برنامهاى كناى كنترل

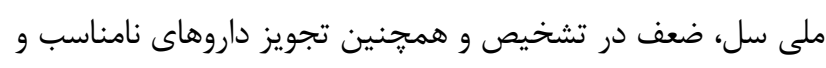

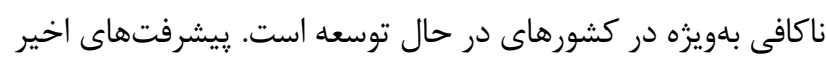

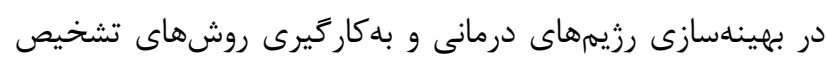

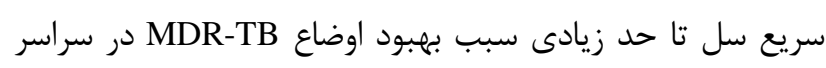

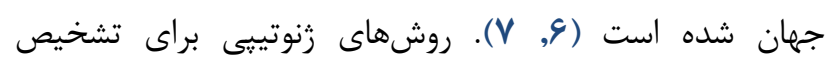

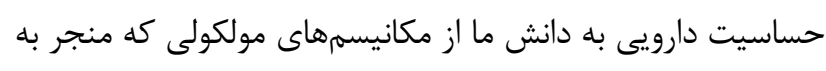

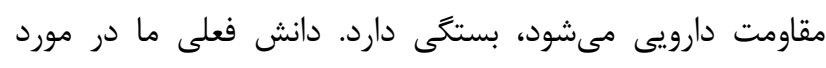

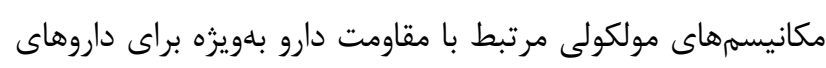

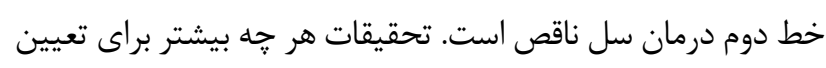

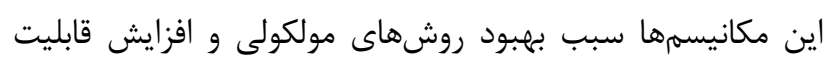

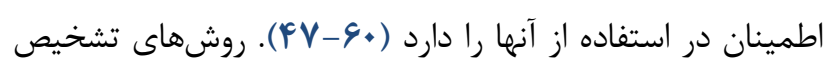

\section{روش GenoType MTBDR plus (Hain life sciences)}

اين روش علاوه بر تشخيص موتاسيون در زن rpoB، بهاطور

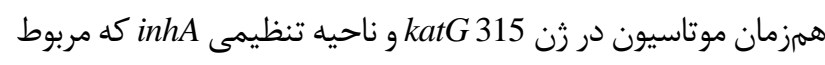
به مقاومت به ايزونيازيد است را شناسايى مي كند (\$1). ويزگى اين روش نسبت به روش

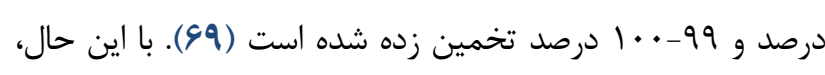

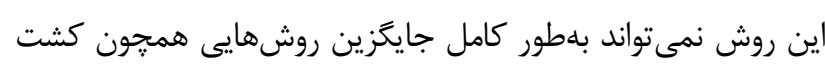

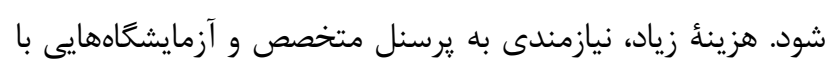
سطح ايمنى بالا از معايب اين روش به شمار مى آيد (99).

\section{^. روش پايروسكوئنسينغ (Pyrosequencing)}

روشى سريع و اتوماتيك تعيين توالى DNA است كه اخيرا براى

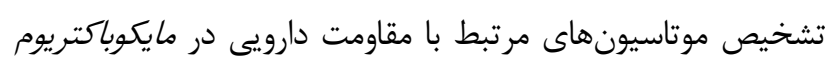

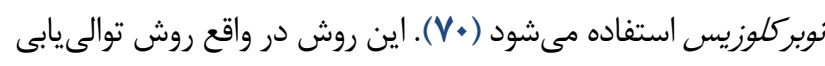

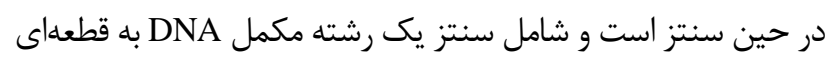

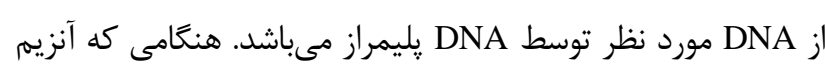
DNA

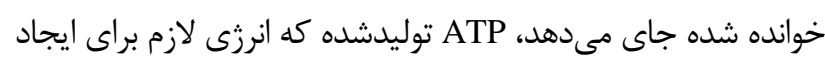

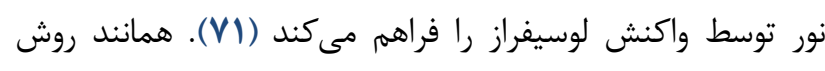

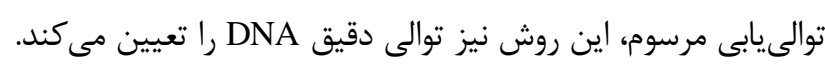

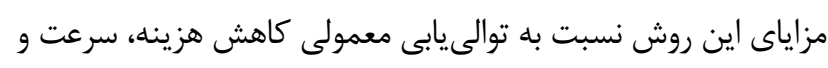

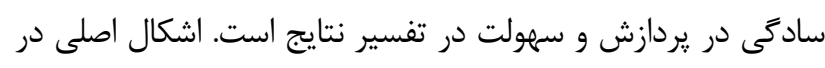
pyrosequencing

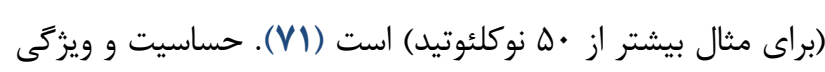

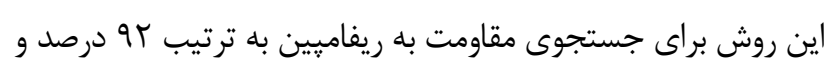

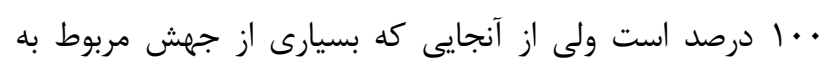

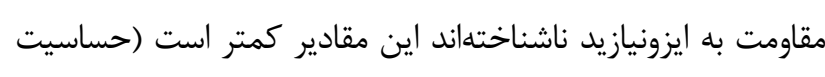

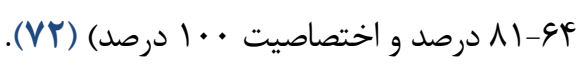

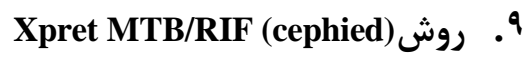

روش Xpret MTB/RIF با تشخيص سريع و همزمان بيمارى سل و مقاومت به ريفاميين، تحولى در كنترل سل ايجاد كرده است.

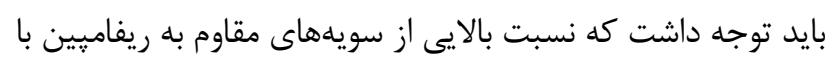

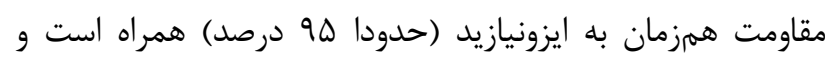

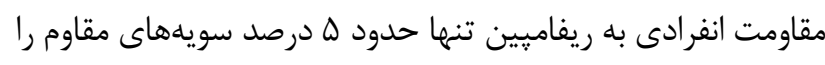

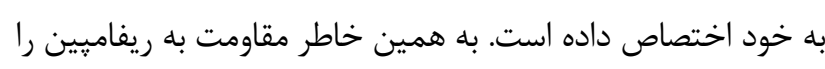

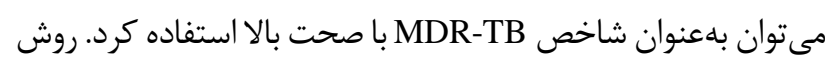

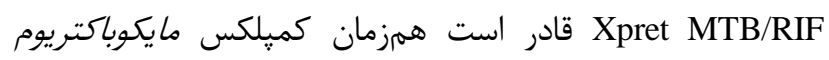


است (Y Y ، YV). بنابراين استفاده از روشهاى مولكولى در رسيدن

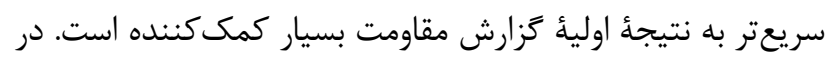

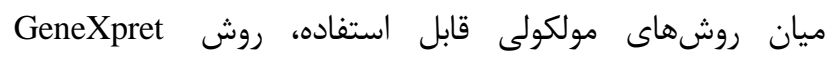
MTB/RIF

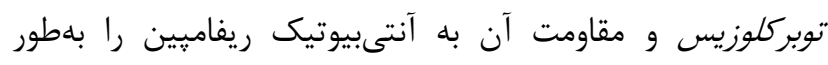
مستقيم از خلط جمع آورى شده در عرض دو ساعت شناسايى كند از دقت، حساسيت و اختصاصيت قابل قبولى برخوردار است. تنها

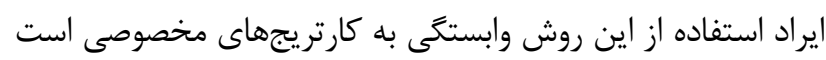
كه لزوما از خارج از كشور وارد مىشود (VY-VF). بنابراين توصيه مىشود كه حتما يك روش مولكولى مناسب ديگر كه از دقت

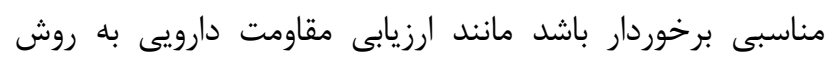
TaqMan Real time PCR

$$
\text { سياسگزן ارى }
$$

$$
\begin{aligned}
& \text { از تمامى همكارانى كه در انجام اين يزوهش ما را يارى } \\
& \text { رساندند، سياسگزاريم. } \\
& \text { تعارض در منافع }
\end{aligned}
$$

در انجام مطالعئ حاضر، نويسندگًان هيجز گونه تضاد منافعى

نداشتهاند.

\section{Referance}

1. Seung KJ, Keshavjee S, Rich ML. Multidrug-resistant tuberculosis and extensively drug-resistant tuberculosis. Cold Spring Harbor perspectives in medicine. 2015;5(9):a017863. [DOI:10.1101/cshperspect.a017863] [PMID] [PMCID]

2. (WHO) WHO. Global tuberculosis report 2019. WHO. 2019.

3. Pfyffer GE, Vincent V. Mycobacterium tuberculosis Complex, Mycobacterium leprae, and Other SlowGrowing Mycobacteria. Topley \& Wilson's Microbiology and Microbial Infections 2010 . [DOI:10.1002/9780470688618.taw0046]

4. Seung KJ, Keshavjee S, Rich ML. Multidrug-Resistant Tuberculosis and Extensively Drug-Resistant Tuberculosis. Cold Spring Harbor perspectives in medicine. 2015;5(9):a017863-a. [DOI:10.1101/cshperspect.a017863] [PMID] [PMCID]

5. Gandhi NR, Nunn P, Dheda K, Schaaf HS, Zignol M, van Soolingen D, et al. Multidrug-resistant and extensively drug-resistant tuberculosis: a threat to global control of tuberculosis. Lancet (London, England). 2010;375(9728):1830-43. [DOI:10.1016/S0140-
مقاومت به داروهاى خط اول و دوم درمان سل نه تنها بايد از دقت بالايى برخوردار باشند بلكه بايد اين مورد را نيز در نظر داشت كه

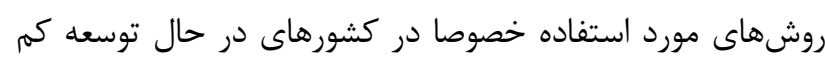
هزينه و در دسترس عموم آزمايشگاههاى ميكروبيولوزى باشد. روشهاى تشخيص مولكولى به همراه روشهاى فنوتييى براى تاييد سويههاى مشكوى به MDR-TB مناسب و قابل اجرا هستند و نتيجهاى ارزشمند را در تركيب با روشهاى فنوتييى ارائه مي دهند. اخيرا روشهاى سريع و مقرون به صرفه براى كشت و تعيين

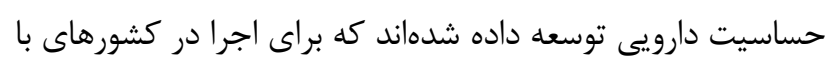
درآمد اندى و مناطق اندميك كارآمد هستند. ارائه دستورالعمل و

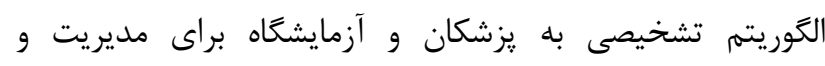

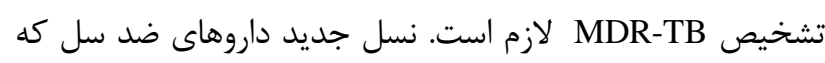
در مراحل مختلف توليد و توسعه هستند مى توانند اميدوارى براى بهبود وضعيت گزينههاى درمانى در برابر سل و سل مقاوم به درمان

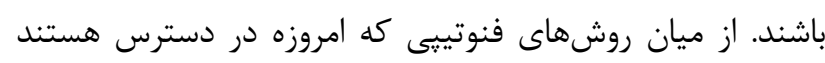
روش نسبى بررسى مقاومت دارويى در مقايسه با ساير روشها از حساسيت و اختصاصيت بالايى برخوردار است خصوصا اتر كاربرى

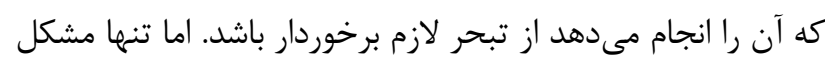
روش نسبى مدت زمان نسبتا طولانى مورد نياز براى گزارش نتيجه

6. Zainuddin ZF, Dale JW. Does Mycobacterium tuberculosis have plasmids? Tubercle. 1990;71(1):43-9. [DOI:10.1016/0041-3879(90)90060-L]

7. Nagai Y, Iwade Y, Hayakawa E, Nakano M, Sakai T, Mitarai S, et al. High resolution melting curve assay for rapid detection of drug-resistant Mycobacterium tuberculosis. Journal of infection and chemotherapy : official journal of the Japan Society of Chemotherapy. 2013;19(6):1116-25. [DOI:10.1007/s10156-013-0636-3] [PMID]

8. Vilcheze C, Jacobs WR, Jr. The mechanism of isoniazid killing: clarity through the scope of genetics. Annual review of microbiology. 2007;61:35-50. [DOI:10.1146/annurev.micro.61.111606.122346] [PMID]

9. Caminero JA, Sotgiu G, Zumla A, Migliori GB. Best drug treatment for multidrug-resistant and extensively drugresistant tuberculosis. The Lancet Infectious diseases. 2010;10(9):621-9. [DOI:10.1016/S1473-3099(10)701390]

10. Zhang Y, Heym B, Allen B, Young D, Cole S. The catalase-peroxidase gene and isoniazid resistance of Mycobacterium tuberculosis. Nature. 1992;358(6387):591-3. [DOI:10.1038/358591a0] [PMID] 
11. Seifert M, Catanzaro D, Catanzaro A, Rodwell TC. Genetic mutations associated with isoniazid resistance in Mycobacterium tuberculosis: a systematic review. PloS one. 2015;10(3):e0119628-e. [DOI:10.1371/journal.pone.0119628] [PMID] [PMCID]

12. Ando H, Kondo Y, Suetake T, Toyota E, Kato S, Mori T, et al. Identification of $\mathrm{katG}$ mutations associated with high-level isoniazid resistance in Mycobacterium tuberculosis. Antimicrobial agents and chemotherapy. 2010;54(5):1793-9.

[DOI:10.1128/AAC.01691-09] [PMID] [PMCID]

13. Hazbon $\mathrm{MH}$, Brimacombe M, Bobadilla del Valle M, Cavatore M, Guerrero MI, Varma-Basil M, et al. Population genetics study of isoniazid resistance mutations and evolution of multidrug-resistant Mycobacterium tuberculosis. Antimicrobial agents and chemotherapy. 2006;50(8):2640-9. [DOI:10.1128/AAC.00112-06] [PMID] [PMCID]

14. Timmins GS, Deretic V. Mechanisms of action of isoniazid. Molecular microbiology. 2006;62(5):1220-7. [DOI:10.1111/j.1365-2958.2006.05467.x] [PMID]

15. Cardoso RF, Cardoso MA, Leite CQ, Sato DN, Mamizuka EM, Hirata RD, et al. Characterization of ndh gene of isoniazid resistant and susceptible Mycobacterium tuberculosis isolates from Brazil. Memorias do Instituto Oswaldo Cruz. 2007;102(1):59-61. [DOI:10.1590/S007402762007000100009] [PMID]

16. Rindi L, Bianchi L, Tortoli E, Lari N, Bonanni D, Garzelli C. Mutations responsible for Mycobacterium tuberculosis isoniazid resistance in Italy. The international journal of tuberculosis and lung disease : the official journal of the International :union: against Tuberculosis and Lung Disease. 2005;9(1):94-7.

17. Snell J, Arora K. Mechanism of action of antimicrobial and antitumor agents: Springer Science \& Business Media; 2012.

18. Campbell EA, Korzheva N, Mustaev A, Murakami K, Nair S, Goldfarb A, et al. Structural mechanism for rifampicin inhibition of bacterial RNA polymerase. Cell. 2001;104(6):901-12.

[DOI:10.1016/S00928674(01)00286-0]

19. Telenti A, Imboden P, Marchesi F, Matter L, Schopfer K, Bodmer $\mathrm{T}$, et al. Detection of rifampicin-resistance mutations in Mycobacterium tuberculosis. The Lancet. 1993;341(8846):647-51.

[DOI:10.1016/01406736(93)90417-F]

20. Brandis G, Wrande M, Liljas L, Hughes D. Fitnesscompensatory mutations in rifampicin-resistant RNA polymerase. Molecular microbiology. 2012;85(1):142-51. [DOI:10.1111/j.1365-2958.2012.08099.x] [PMID]

21. Laurenzo D, Mousa SA. Mechanisms of drug resistance in Mycobacterium tuberculosis and current status of rapid molecular diagnostic testing. Acta tropica. 2011;119(1):510. [DOI:10.1016/j.actatropica.2011.04.008] [PMID]

22. Ohno H, Koga H, Kuroita T, Tomono K, Ogawa K, Yanagihara $\mathrm{K}$, et al. Rapid prediction of rifampin susceptibility of Mycobacterium tuberculosis. American journal of respiratory and critical care medicine.
1997;155(6):2057-63.

[DOI:10.1164/ajrccm.155.6.9196115] [PMID]

23. Johnson R, Streicher EM, Louw GE, Warren RM, van Helden PD, Victor TC. Drug resistance in Mycobacterium tuberculosis. Current issues in molecular biology. 2006;8(2):97-111.

24. Chaves F, Alonso-Sanz M, Rebollo M, Tercero J, Jimenez $\mathrm{M}$, Noriega A. rpoB mutations as an epidemiologic marker in rifampin-resistant Mycobacterium tuberculosis. The International Journal of Tuberculosis and Lung Disease. 2000;4(8):765-70.

25. CNTC. Drug-resistant tuberculosis: a survival guide for clinicians. 2nd edition. 2008. p. 1-266.

26. Beckers B, Lang H, Schimke D, Lammers A. Evaluation of a bioluminescence assay for rapid antimicrobial susceptibility testing of mycobacteria. European journal of clinical microbiology. 1985;4(6):556-61. [DOI:10.1007/BF02013394] [PMID]

27. Amini S, Hoffner S, Allahyar Torkaman MR, Hamzehloo G, Nasiri MJ, Salehi M, Sami Kashkooli G, Shahraki MS, Mohsenpoor M, Soleimanpour S, Mir R. Direct drug susceptibility testing of Mycobacterium tuberculosis using the proportional method: A multicenter study. J Glob Antimicrob Resist. 2019;17:242-244. [DOI:10.1016/j.jgar.2018.12.022] [PMID]

28. Gupta A, Anupurba S. Direct drug susceptibility testing of Mycobacterium tuberculosis against primary anti-TB drugs in northern India. Journal of infection in developing countries. 2010;4:695-703. [DOI:10.3855/jidc.1079] [PMID]

29. Canetti G, Froman S, Grosset Ja, Hauduroy P, Langerova M, Mahler H, et al. Mycobacteria: laboratory methods for testing drug sensitivity and resistance. Bulletin of the World Health Organization. 1963;29(5):565.

30. Rusch-Gerdes S, Domehl C, Nardi G, Gismondo MR, Welscher HM, Pfyffer GE. Multicenter evaluation of the mycobacteria growth indicator tube for testing susceptibility of Mycobacterium tuberculosis to first-line drugs. J Clin Microbiol. 1999;37(1):45-8. [DOI:10.1128/JCM.37.1.45-48.1999] [PMID] [PMCID]

31. Roberts G, Goodman N, Heifets L, Larsh H, Lindner T, McClatchy $J$, et al. Evaluation of the BACTEC radiometric method for recovery of mycobacteria and drug susceptibility testing of Mycobacterium tuberculosis from acid-fast smear-positive specimens. Journal of clinical microbiology. 1983;18(3):689-96. [DOI:10.1128/JCM.18.3.689-696.1983] [MID] [PMCID]

32. Anargyros P, Astill DS, Lim IS. Comparison of improved BACTEC and Lowenstein-Jensen media for culture of mycobacteria from clinical specimens. Journal of clinical microbiology. 1990;28(6):1288-91. [DOI:10.1128/JCM.28.6.1288-1291.1990] [PMID] [PMCID]

33. Ahmad S, Mokaddas E. Recent advances in the diagnosis and treatment of multidrug-resistant tuberculosis. Respiratory medicine. 2009;103(12):1777-90. [DOI:10.1016/j.rmed.2009.07.010] [PMID] 
34. Tortoli E, Cichero P, Piersimoni C, Simonetti MT, Gesu G, Nista D. Use of BACTEC MGIT 960 for recovery of mycobacteria from clinical specimens: multicenter study. Journal of clinical microbiology. 1999;37(11):3578-82. [DOI:10.1128/JCM.37.11.3578-3582.1999] [PMID] [PMCID]

35. Gravet A, Souillard N, Habermacher J, Moser A, Lohmann C, Schmitt F, et al. Culture and susceptibility testing of mycobacteria with VersaTREK. Pathologiebiologie. 2011;59:32-8 [DOI:10.1016/j.patbio.2010.08.003] [PMID]

36. Gravet A, Souillard N, Habermacher J, Moser A, Lohmann C, Schmitt F, et al. [Culture and susceptibility testing of mycobacteria with VersaTREK]. Pathol Biol (Paris). 2011;59(1):32-8 [DOI:10.1016/j.patbio.2010.08.003] [PMID]

37. Wilson SM, Al-Suwaidi Z, McNerney R, Porter J, Drobniewski F. Evaluation of a new rapid bacteriophagebased method for the drug susceptibility testing of Mycobacterium tuberculosis. Nature medicine. 1997;3(4):465-8. [DOI:10.1038/nm0497-465] [PMID]

38. Banaiee N, Bobadilla-Del-Valle M, Bardarov S, Jr., Riska PF, Small PM, Ponce-De-Leon A, et al. Luciferase reporter mycobacteriophages for detection, identification, and antibiotic susceptibility testing of Mycobacterium tuberculosis in Mexico. J Clin Microbiol. 2001;39(11):3883-8. [DOI:10.1128/JCM.39.11.38833888.2001] [PMID] [PMCID]

39. Kalokhe AS, Lee JC, Ray SM, Anderson AM, Nguyen MLT, Wang YF, et al. Multidrug-resistant tuberculosis drug susceptibility and molecular diagnostic testing. The American journal of the medical sciences. 2013;345(2):143-8.

[DOI:10.1097/MAJ.0b013e31825d32c6]

[PMID] [PMCID]

40. Boum Y, 2nd, Orikiriza P, Rojas-Ponce G, Riera-Montes M, Atwine D, Nansumba M, et al. Use of colorimetric culture methods for detection of Mycobacterium tuberculosis complex isolates from sputum samples in resource-limited settings. Journal of clinical microbiology. 2013;51(7):2273-9. [DOI:10.1128/JCM.00749-13] [PMID] [PMCID]

41. Raut U, Narang P, Mendiratta DK, Narang R, Deotale V. Evaluation of rapid MTT tube method for detection of drug susceptibility of Mycobacterium tuberculosis to rifampicin and isoniazid. Indian journal of medical microbiology. 2008;26(3):222-7. [DOI:10.4103/02550857.39586] [PMID]

42. Kohli A, Bashir G, Fatima A, Jan A, Wani N-u-d, Ahmad J. Rapid drug-susceptibility testing of Mycobacterium tuberculosis clinical isolates to first-line antitubercular drugs by nitrate reductase assay: A comparison with proportion method. International Journal of Mycobacteriology. 2016;5(4):469-74. [DOI:10.1016/j.ijmyco.2016.06.006] [PMID]

43. Angeby KA, Klintz L, Hoffner SE. Rapid and inexpensive drug susceptibility testing of Mycobacterium tuberculosis with a nitrate reductase assay. J Clin Microbiol.
2002;40(2):553-5. 555.2002] [PMID] [PMCID]

44. Montoro E, Lemus D, Echemendia M, Martin A, Portaels F, Palomino JC. Comparative evaluation of the nitrate reduction assay, the MTT test, and the resazurin microtitre assay for drug susceptibility testing of clinical isolates of Mycobacterium tuberculosis. The Journal of antimicrobial chemotherapy. 2005;55(4):500-5. [DOI:10.1093/jac/dki023] [PMID]

45. Martin A, Montoro E, Lemus D, Simboli N, Morcillo N, Velasco $\mathrm{M}$, et al. Multicenter evaluation of the nitrate reductase assay for drug resistance detection of Mycobacterium tuberculosis. Journal of microbiological methods. 2005;63(2):145-50. [DOI:10.1016/j.mimet.2005.03.004] [PMID]

46. Newton CR, Graham A, Heptinstall LE, Powell SJ, Summers C, Kalsheker N, et al. Analysis of any point mutation in DNA. The amplification refractory mutation system (ARMS). Nucleic acids research. 1989;17(7):2503-16. [DOI:10.1093/nar/17.7.2503] [PMID] [PMCID]

47. Ugozzoli L, Wallace RB. Allele-specific polymerase chain reaction. Methods.1991;2(1):42-8. [DOI:10.1016/S1046-2023(05)80124-0]

48. Little S. Amplification-refractory mutation system (ARMS) analysis of point mutations. Current protocols in human genetics. 2001; Chapter 9:Unit 9.8.

49. Sisay T, Berhane N, Verma D. Molecular Biology Drug Resistance Mechanisms and Molecular Diagnosis Methods for Tuberculosis. Molecular Biology: Open Access. 2019;8:230.

50. Ho PL, Yam WC, Leung CC, Yew WW, Mok TY, Chan $\mathrm{KS}$, et al. Molecular tests for rapid detection of rifampicin and isoniazid resistance in Mycobacterium tuberculosis. Hong Kong medical journal = Xianggang yi xue za zhi. 2015;21 Suppl 4:4-7.

51. Xu H-B, Jiang R-H, Sha W, Li L, Xiao H-P. PCR-SingleStrand Conformational Polymorphism Method for Rapid Detection of Rifampin-Resistant Mycobacterium tuberculosis: Systematic Review and Meta-Analysis. Journal of Clinical Microbiology. 2010;48(10):3635-40. [DOI:10.1128/JCM.00960-10] [PMID] [PMCID]

52. Kim BJ, Kim SY, Park BH, Lyu MA, Park IK, Bai GH, et al. Mutations in the rpoB gene of Mycobacterium tuberculosis that interfere with PCR-single-strand conformation polymorphism analysis for rifampin susceptibility testing. Journal of clinical microbiology. 1997;35(2):492-4. 494.1997] [PMID] [PMCID]

53. Shima K, Wu Y, Sugimoto N, Asakura M, Nishimura K, Yamasaki S. Comparison of a PCR-Restriction Fragment Length Polymorphism (PCR-RFLP) Assay to PulsedField Gel Electrophoresis To Determine the Effect of Repeated Subculture and Prolonged Storage on RFLP Patterns of Shiga Toxin-Producing Escherichia coli O157:H7. Journal of Clinical Microbiology. 2006;44(11):3963-8. [DOI:10.1128/JCM.00717-06] [PMID] [PMCID] 
54. Victor TC, van Helden PD, Warren R. Prediction of drug resistance in $\mathrm{M}$. tuberculosis: molecular mechanisms, tools, and applications. IUBMB life. 2002;53(4-5):231-7. [DOI:10.1080/15216540212642] [PMID]

55. Ahmad S, Mokaddas E, Jaber AA. Rapid detection of ethambutol-resistant Mycobacterium tuberculosis strains by PCR-RFLP targeting embB codons 306 and 497 and iniA codon 501 mutations. Molecular and cellular probes. 2004;18(5):299-306. [DOI:10.1016/j.mcp.2004.04.001] [PMID]

56. Shamputa IC, Rigouts, Portaels F. Molecular genetic methods for diagnosis and antibiotic resistance detection of mycobacteria from clinical specimens. APMIS : acta pathologica, microbiologica, et immunologica Scandinavica. 2004;112(11-12):728-52. [DOI:10.1111/j.1600-0463.2004.apm11211-1203.x] [PMID]

57. Ruiz M, Torres MJ, Llanos AC, Arroyo A, Palomares JC, Aznar J. Direct detection of rifampin- and isoniazidresistant Mycobacterium tuberculosis in auraminerhodamine-positive sputum specimens by real-time PCR. Journal of clinical microbiology. 2004;42(4):1585-9. [DOI:10.1128/JCM.42.4.1585-1589.2004] [PMID] [PMCID]

58. Riahi F, Derakhshan M, Mosavat A, Soleimanpour S, Rezaee SA. Evaluation of Point Mutation Detection in Mycobacterium tuberculosis with Isoniazid Resistance Using Real-Time PCR and TaqMan Probe Assay. Applied Biochemistry and Biotechnology. 2015; 175 (5): 24472455. [DOI:10.1007/s12010-014-1442-9] [PMID]

59. Watanabe Pinhata JM, Cergole-Novella MC, Moreira dos Santos Carmo A, Ruivo Ferro e Silva R, Ferrazoli L, Tavares Sacchi C, et al. Rapid detection of Mycobacterium tuberculosis complex by real-time PCR in sputum samples and its use in the routine diagnosis in a reference laboratory. Journal of medical microbiology. 2015;64(9):1040-5. [DOI:10.1099/jmm.0.000121] [PMID]

60. Parashar D, Chauhan DS, Sharma VD, Katoch VM. Applications of real-time PCR technology to mycobacterial research. The Indian journal of medical research. 2006;124(4):385-98.

61. Ririe KM, Rasmussen RP, Wittwer CT. Product differentiation by analysis of DNA melting curves during the polymerase chain reaction. Analytical biochemistry. 1997;245(2):154-60.

[DOI:10.1006/abio.1996.9916] [PMID]

62. Wittwer CT, Reed GH, Gundry CN, Vandersteen JG, Pryor RJ. High-resolution genotyping by amplicon melting analysis using LCGreen. Clinical chemistry. 2003;49(6 Pt 1):853-60. [DOI:10.1373/49.6.853] [PMID]

63. Landolt P, Stephan R, Scherrer S. Development of a new High Resolution Melting (HRM) assay for identification and differentiation of Mycobacterium tuberculosis complex samples. Scientific Reports. 2019;9(1):1850. [DOI:10.1038/s41598-018-38243-6] [PMID] [PMCID]

64. Alonso M, Navarro Y, Barletta F, Lirola MM, Gotuzzo E, Bouza E, et al. A novel method for the rapid and prospective identification of Beijing Mycobacterium tuberculosis strains by high-resolution melting analysis. Clinical Microbiology and Infection. 2011;17(3):349-57. [DOI:10.1111/j.1469-0691.2010.03234.x] [PMID]

65. Pietzka AT, Indra A, Stöger A, Zeinzinger J, Konrad M, Hasenberger P, et al. Rapid identification of multidrugresistant Mycobacterium tuberculosis isolates by rpoB gene scanning using high-resolution melting curve PCR analysis. Journal of antimicrobial chemotherapy. 2009;63(6):1121-7. [DOI:10.1093/jac/dkp124] [PMID]

66. Ong DCT, Yam W-C, Siu GKH, Lee ASG. Rapid detection of rifampicin- and isoniazid-resistant Mycobacterium tuberculosis by high-resolution melting analysis. Journal of clinical microbiology. 2010;48(4):1047-54. [DOI:10.1128/JCM.02036-09] [PMID] [PMCID]

67. Traore H, van Deun A, Shamputa IC, Rigouts L, Portaels F. Direct detection of Mycobacterium tuberculosis complex DNA and rifampin resistance in clinical specimens from tuberculosis patients by line probe assay. Journal of clinical microbiology. 2006;44(12):4384-8. [DOI:10.1128/JCM.01332-06] [PMID] [PMCID]

68. Hillemann D, Rusch-Gerdes S, Richter E. Evaluation of the GenoType MTBDRplus assay for rifampin and isoniazid susceptibility testing of Mycobacterium tuberculosis strains and clinical specimens. J Clin Microbiol. 2007;45(8):2635-40. [DOI:10.1128/JCM.00521-07] [PMID] [PMCID]

69. Giannoni F, Iona E, Sementilli F, Brunori L, Pardini M, Migliori GB, et al. Evaluation of a new line probe assay for rapid identification of gyrA mutations in Mycobacterium tuberculosis. Antimicrobial agents and chemotherapy. 2005;49(7):2928-33. [DOI:10.1128/AAC.49.7.2928-2933.2005] [PMID] [PMCID]

70. Marttila HJ, Makinen J, Marjamaki M, Soini H. Prospective evaluation of pyrosequencing for the rapid detection of isoniazid and rifampin resistance in clinical Mycobacterium tuberculosis isolates. European journal of clinical microbiology \& infectious diseases : official publication of the European Society of Clinical Microbiology. 2009;28(1):33-8. [DOI:10.1007/s10096008-0584-5] [PMID]

71. Jureen P, Engstrand L, Eriksson S, Alderborn A, Krabbe M, Hoffner SE. Rapid detection of rifampin resistance in Mycobacterium tuberculosis by Pyrosequencing technology. J Clin Microbiol. 2006;44(6):1925-9. [DOI:10.1128/JCM.02210-05] [PMID] [PMCID]

72. Zhao JR, Bai YJ, Wang Y, Zhang QH, Luo M, Yan XJ. Development of a pyrosequencing approach for rapid screening of rifampin, isoniazid and ethambutol-resistant Mycobacterium tuberculosis. The international journal of tuberculosis and lung disease : the official journal of the International :union: against Tuberculosis and Lung Disease. 2005;9(3):328-32.

73. Friedrich SO, von Groote-Bidlingmaier F, Diacon AH. Xpert MTB/RIF Assay for Diagnosis of Pleural Tuberculosis. Journal of Clinical Microbiology. 2011;49(12):4341-2. [DOI:10.1128/JCM.05454-11] [PMID] [PMCID] 
74. Ioannidis P, Papaventsis D, Karabela S, Nikolaou S, Panagi M, Raftopoulou E, et al. Cepheid GeneXpert MTB/RIF Assay for Mycobacterium tuberculosis Detection and Rifampin Resistance Identification in Patients with Substantial Clinical Indications of Tuberculosis and Smear-Negative Microscopy Results. Journal of Clinical Microbiology. 2011;49(8):3068-70. [DOI:10.1128/JCM.00718-11] [PMID] [PMCID]

75. Boehme CC, Nicol MP, Nabeta P, Michael JS, Gotuzzo E, Tahirli R, et al. Feasibility, diagnostic accuracy, and effectiveness of decentralised use of the Xpert MTB/RIF test for diagnosis of tuberculosis and multidrug resistance: a multicentre implementation study. Lancet (London, England). 2011;377(9776):1495-505. [DOI:10.1016/S0140-6736(11)60438-8]

76. Noor KM, Shephard L, Bastian I. Molecular diagnostics for tuberculosis. Pathology. 2015;47(3):250-6. [DOI:10.1097/PAT.0000000000000232] [PMID] 